\title{
Treatment of Cushing's disease: a mechanistic update
}

\author{
Daniel Cuevas-Ramos ${ }^{1,2}$ and Maria Fleseriu ${ }^{3}$ \\ ${ }^{1}$ Department of Medicine, Pituitary Center, Cedars-Sinai Medical Center, Los Angeles, California, USA \\ ${ }^{2}$ Neuroendocrinology Clinic, Department of Endocrinology and Metabolism, Instituto Nacional de Ciencias \\ Médicas y Nutrición Salvador Zubirán, Mexico City, Mexico \\ ${ }^{3}$ Departments of Medicine and Neurological Surgery, and Northwest Pituitary Center, Oregon Health \& Science \\ University, 3181 SW Sam Jackson Park Road (BTE 472), Portland, Oregon 97239, USA
}

Correspondence should be addressed to M Fleseriu

Email fleseriu@ohsu.edu

\begin{abstract}
Cushing's disease (CD) is characterized by an ACTH-producing anterior corticotrope pituitary adenoma. If hypothalamus-pituitary-adrenal (HPA) axis physiology is disrupted, ACTH secretion increases, which in turn stimulates adrenocortical steroidogenesis and cortisol production. Medical treatment plays an important role for patients with persistent disease after surgery, for those in whom surgery is not feasible, or while awaiting effects of radiation. Multiple drugs, with different mechanisms of action and variable efficacy and tolerability for controlling the deleterious effects of chronic glucocorticoid excess, are available. The molecular basis and clinical data for centrally acting drugs, adrenal steroidogenesis inhibitors, and glucocorticoid receptor antagonists are reviewed, as are potential novel molecules and future possible targets for CD treatment. Although progress has been made in the understanding of specific corticotrope adenoma receptor physiology and recent clinical studies have detected improved effects with a combined medical therapy approach, there is a clear need for a more efficacious and better-tolerated medical therapy for patients with CD. A better understanding of the molecular mechanisms in CD and of HPA axis physiology should advance the development of new drugs in the future.
\end{abstract}
Key Words
- cortisol
- Cushing's disease
- ACTH
- pasireotide
- mifepristone
- ketoconazole
- LCl699
- cabergoline

\section{Introduction}

Cushing's disease (CD) is caused by an adrenocorticotropin (ACTH)-secreting pituitary tumor that stimulates cortisol production by the adrenal glands. Morbidity and mortality are significantly increased if hypercortisolemia is left untreated. Transsphenoidal surgery, performed by an experienced neurosurgeon, is currently considered the first-line treatment. Medical treatment is commonly used to control the deleterious effects of persistent chronic glucocorticoid excess and 24-h urinary free cortisol (UFC) normalization still represents the gold standard to evaluate the efficacy of most medical treatments.

Glucocorticoid exerts effects through the glucocorticoid receptor (GR) and as the GR is expressed in almost every human tissue, conditions of glucocorticoid excess, such as CD, result in deleterious effects on cell metabolism. Pharmacological agents can be classified as adrenal steroidogenesis blockers, centrally acting drugs, and GR antagonists. Recent research has evaluated chimeric compounds that work synergistically through membrane interaction or dimerization of both somatostatin receptors (SSTRs) and dopamine D2 receptors in corticotrope cells. Although no available medical agents surpass the efficacy of surgical therapy, new treatments acting directly at the pituitary adenoma have been approved for use and highlight the importance of targeting the pituitary corticotrope. A review of the

Published by Bioscientifica Ltd 
mechanisms of current and future medical treatment modalities for CD is provided.

\section{Overview of CD therapy}

Cushing's syndrome (CS) is characterized by chronic overproduction of cortisol resulting in significant morbidity and, when left untreated, increased mortality (Newell-Price et al. 2006, Dekkers et al. 2007). CS is classified as ACTHdependent and -independent. The most common etiology (70-80\%) of CS is CD, caused by an ACTH-secreting pituitary adenoma or, more rarely, by ectopic ACTH or corticotropin-releasing hormone $(\mathrm{CRH})$ production that may result in corticotrope hyperplasia (Newell-Price et al. 2006, Biller et al. 2008). Chronic cortisol excess leads to a typical clinical phenotype (Table 1). Although epidemiological data on $\mathrm{CD}$ are limited, population-based studies indicate an incidence of 1.2-2.4 per million (Arnardottir \& Sigurjonsdottir 2011, Bolland et al. 2011) with a prevalence of approximately 39 per million population (Feelders et al. 2012). Compared with the general population or patients with other pituitary adenomas, patients with hypercortisolism have a four times higher mortality risk if untreated and cardiovascular disease remains the leading cause of death (Newell-Price et al. 2006, Dekkers et al. 2007, Feelders \& Hofland 2013).

Transsphenoidal surgery is the first line therapy achieving $65-90 \%$ disease remission for microadenomas (tumors $<1 \mathrm{~cm}$; Biller et al. 2008, Tritos et al. 2011, Fleseriu $2012)$, and lower remission rates $(<65 \%)$ for macroadenomas (tumors $>1 \mathrm{~cm}$ ) (Aghi 2008). The risk of CD recurrence can reach 25\%, 3 years after surgery (Patil et al. 2008). Second and third line therapies such as a second pituitary surgery (Patil et al. 2008, Fleseriu 2012), pituitary irradiation (conventional and/or stereotactic) (Estrada et al. 1997, Tritos et al. 2011) and bilateral adrenalectomy (Young \& Thompson 2005, Assie et al. 2007, Chow et al. 2008, Ritzel et al. 2013) have been utilized with variable results and specific complications.

\section{Targets for medical treatment of CD}

The hypothalamus-pituitary-adrenal (HPA) axis is organized into three regions: the hypothalamus, pituitary gland, and adrenal glands (Fig. 1). CD is caused by a pituitary tumor; therefore, medical therapy should ideally

Table 1 Clinical features and associated morbidity observed in Cushing's syndrome

\begin{tabular}{lc}
\hline Clinical features & Frequency (\%) \\
\hline Increased weight (centripetal obesity, supraclavicular region, and upper back) & $80-95$ \\
Skin changes (round face, facial plethora, and skin atrophy) & $80-90$ \\
Decreased libido & $25-90$ \\
Menstrual irregularity & $75-80$ \\
Muscle proximal weakness & $60-80$ \\
Hirsutism & $70-75$ \\
Violaceous striae & $55-65$ \\
Easy bruising & $45-65$ \\
Associated morbidity & $40-95$ \\
Obesity & $60-80$ \\
Hypertension & $50-80$ \\
Glucose intolerance or diabetes mellitus & $40-75$ \\
Osteoporosis & $50-70$ \\
Psychiatric symptoms & $40-70$ \\
Dyslipidemia & $15-30$ \\
Increased infections and decreased wound healing & $15-20$ \\
Renal calculi & $10-20$ \\
Venous thromboembolism & $5-10$ \\
Avascular necrosis in femoral head & \\
Specific for Cushing's disease & $0-37$ \\
Headaches & $0-33$ \\
Visual problems (bitemporal hemianopsia) & $0-25$ \\
Other anterior pituitary hormone deficiencies & \\
Alterations with severe hypercortisolism & $10-50$ \\
Weight reduction (with ectopic ACTH secretion by malignancy) & $15-35$ \\
Hypoalbuminemia & $10-15$ \\
Hypokalemia and metabolic alkalosis & $4-10$ \\
\hline
\end{tabular}

Boscaro et al. (2001), Newell-Price et al. (2006), Biller et al. (2008), Bertagna (2006), and Greenman (2010).

http://joe.endocrinology-journals.org DOI: $10.1530 / J O E-14-0300$ (c) 2014 Society for Endocrinology Printed in Great Britain
Published by Bioscientifica Ltd 


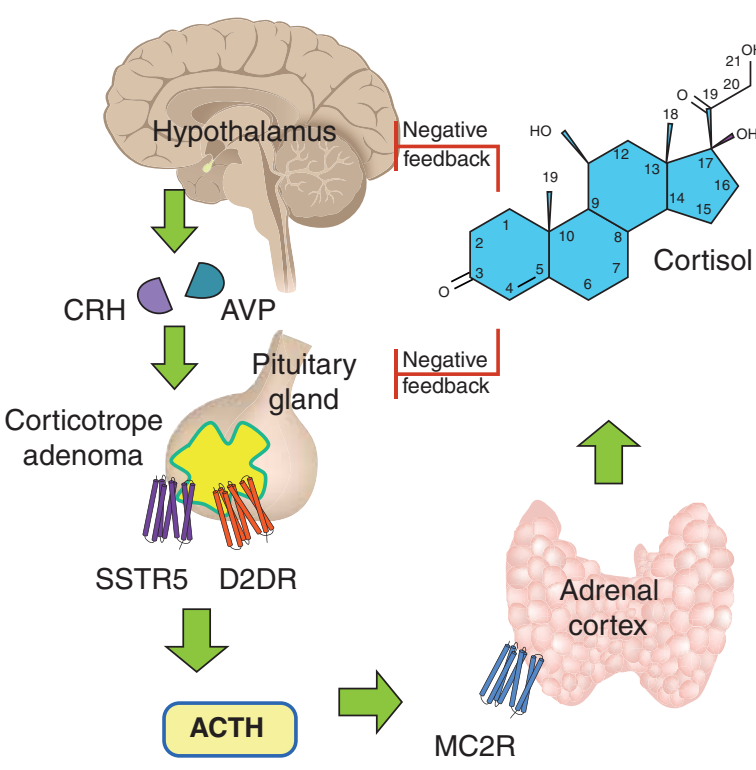

\begin{tabular}{|l|}
\hline Centrally acting drugs \\
\hline Serotoninergic antagonists \\
\hline Others \\
\hline GABA agonists \\
\hline Valproic acid \\
\hline SRLs \\
\hline Pasireotide \\
\hline Dopamine agonists \\
\hline Cabergoline \\
\hline Chimeric compounds \\
\hline Dopastatin \\
\hline Retinoic acid \\
\hline Temozolomide \\
\hline Steroidogenesis blockers \\
\hline Imidazoles \\
\hline Ketoconazole \\
\hline Fluconazole \\
\hline Etomidate \\
\hline Metyrapone \\
\hline Mitotane \\
\hline LCl699 \\
\hline
\end{tabular}

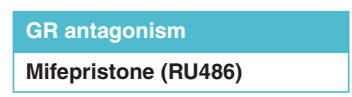

Mifepristone (RU486)
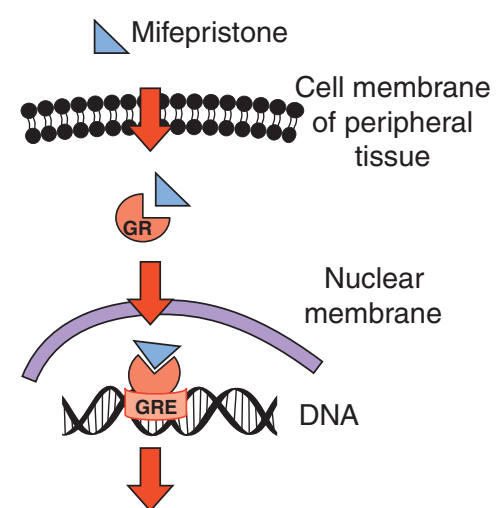

Inhibition of cell transcription

\section{Figure 1}

The hypothalamus-pituitary-adrenal (HPA) axis and targets of drugs used for treating Cushing's disease. Under physiological conditions, cortisol synthesis and production are tightly regulated by the HPA axis. Adrenocorticotropin (ACTH)-producing cells in the anterior pituitary respond to hypothalamic corticotropin-releasing hormone $(\mathrm{CRH})$ and arginine vasopressin (AVP). After binding to melanocortin type 2 receptor (MC2R), ACTH induces the steroidogenic enzymes to increase the biosynthesis of cortisol and will decrease ACTH and CRH secretion. Pituitary corticotrope ACTH-secreting adenomas, however, function autonomously

target the corticotrope cell adenoma. However, as glucocorticoids represent the end hormone of the HPA axis and hypercortisolism induces comorbidities, steroidogenic inhibition was the first therapy used. Indications for medical therapy in patients with $\mathrm{CD}$ are summarized in Table 2.

\section{Adrenal steroidogenesis blockers}

Adrenal cortical atrophy was first documented in dogs treated with the insecticide dichlorodiphenyldichloroethane (DDD; Nelson \& Woodard 1949). This observation led to the development of the use of $\mathrm{o}, \mathrm{p}^{\prime}$-DDD or mitotane, initially for adrenal cancer and CS (Cueto \& Brown 1958, Southren et al. 1961). Subsequently, amphonenone B (Hertz et al. 1956, Thorn et al. 1956), aminoglutethimide (Camacho et al. 1967), metyrapone (Gower 1974), trilostane (Potts et al. 1978), and ketoconazole (Pont et al. 1982) were identified as steroidogenic inhibitors (Fig. 2 and Table 3). and overstimulate cortisol production at the adrenal cortex. The pharmacotherapies for ACTH-secreting pituitary corticotrope adenomas are categorized by the site of action into three groups: i) centrally acting agents or neuromodulators, which inhibit ACTH release from pituitary adenomas, ii) adrenal steroidogenic inhibitors, which block one or several steps in cortisol biosynthesis and iii) the glucocorticoid receptor-blocking agent mifepristone. Green arrows indicate activation and red arrows/lines indicate inhibition.

\section{Ketoconazole}

Introduced as an antifungal agent, ketoconazole exerts endocrine side effects indicating its possible therapeutic efficacy in lowering cholesterol levels. Indeed, the imidazole derivative ketoconazole was noted to cause gynecomastia associated with lower plasma testosterone and cortisol values (Table 3; Pont et al. 1982). Ketoconazole was first used in the treatment of a patient with a cortisol-producing adrenal adenoma in 1983 (Engelhardt et al. 1983), and has been used off-label since then. Ketoconazole inhibits the side-chain cleavage complex (P450scc, CYP11A1, or 20,22 desmolase), 11ß-hydroxylase, and $17 \alpha$-hydroxylase (Table 4 ) (Feldman 1986, Loli etal. 1986). As a result of effective inhibition of cholesterol sidechain cleavage and 17-hydroxylase/17,20 lyase activity, ketoconazole may reduce androgen synthesis; therefore, effects on hirsutism are favorable (Fig. 2). There are inhibitory effects on several cytochrome P450 enzymes, mainly CYP3A4, CYP2C9, and CYP1A2 (Feldman 1986, Feelders et al. 2010a, Fleseriu \& Petersenn 2012),

Published by Bioscientifica Ltd 
Table 2 Use of medical therapy in Cushing's disease indications and needs

Before or after pituitary surgery
Preparation for surgery
Patients with contraindications for surgery
High operation risk
Patients unwilling to undergo surgery
After unsuccessful surgery
Amelioration or control of the metabolic effects of
hypercortisolemia
Potentially life-threatening complications
Patients awaiting effects of pituitary radiation
Whenever a definitive treatment is delayed
Primary medical therapy
Low probability of surgical cure
Unfavorable localization
Invisible adenomas
Adenoma without optic chiasm compression

Fleseriu et al. (2007), Biller et al. (2008), Castinetti et al. (2008), Godbout et al. (2010), Fleseriu (2012), and Feelders \& Hofland (2013).

but minimal effect on aromatase enzyme (Miller \& Crapo 1993).

The first clinical reports on patients with CD described normalization of urinary or plasma cortisol values with ketoconazole doses of 600-1200 mg/day (Loli et al. 1986, Tabarin et al. 1991, Miller \& Crapo 1993). Ketoconazole treatment is usually started at $200 \mathrm{mg}$ twice a day, and biochemical effect is achieved at $600-1200 \mathrm{mg} /$ day (Table 3; Nieman 2002, Fleseriu et al. 2012). It has been suggested that ketoconazole may also have inhibitory effects on ACTH secretion by corticotrope tumor cells as ACTH shows no significant increase despite confirmed reduction in cortisol levels (Loose et al. 1983, Loli et al. 1986, Jimenez-Rema et al. 1989, Tabarin et al. 1991). Escape from pharmacological control has been reported (Sonino et al. 1991). Administered as a monotherapy, ketoconazole decreases cortisol levels in $30-80 \%$ of patients (Sonino et al. 1991, Sonino \& Boscaro 1999, Castinetti et al. 2008). Results from a recent large multicenter retrospective study $(n=200)$ revealed normalization of UFC levels measured at the last follow-up in $49 \%$ of patients (Castinetti et al. 2014). Ketoconazole also blocks the GR at high concentrations in cultured hepatoma cells (Loose et al. 1983). Reportedly, hepatotoxicity (Sonino 1987, Sugar et al. 1987, Tabarin et al. 1991) was mild in the study and resolved after drug withdrawal (Castinetti et al. 2014). Ketoconazole has also been used in older patients ( $>75$ years of age) with good tolerance and disease control (Berwaerts et al. 1998).

The use of ketoconazole has been questioned after warnings from the European Medicine Agencies and the
US Food and Drug Administration (FDA) of potential hepatotoxicity (Castinetti et al. 2014). Long-term safety remains to be prospectively studied. In contrast to mitotane (which causes hypercholesterolemia), ketoconazole interferes with the conversion of lanosterol to cholesterol, leading to low cholesterol concentrations. Ketoconazole absorption requires an acidic environment, precluding the use of proton pump inhibitors or $\mathrm{H}_{2}$ receptor blockers. Currently, drug availability is limited in many countries.

\section{Fluconazole}

Fluconazole appears to have similar effects to ketoconazole; however, data are limited. Fluconazole inhibits 11ß-hydroxylase and 17-hydroxylase activities (Fig. 2) and blocks cortisol production in primary cultures of human adrenocortical cells (van der Pas et al. 2012). Fluconazole has been shown to decrease 11-deoxycortisol production in H295R cells and reduce cortisol secretion in HAC15 cells and primary cultures (van der Pas et al. 2012). In cultures of normal adrenals, fluconazole suppressed corticosterone, 17-hydroxypregnenolone, and androstenedione levels, whereas concentrations of progesterone, deoxycorticosterone, and 11-deoxycortisol were increased (Fig. 2). Fluconazole slightly increased StAR protein mRNA expression (van der Pas et al. 2012). Results from clinical studies indicated that fluconazole at a dose of $100 \mathrm{mg}$ twice a day successfully controlled UFC levels in two patients (Riedl et al. 2006). Together, the results of these in vitro and in vivo studies indicate that fluconazole can be used to control cortisol hypersecretion in patients with CD (Table 3).

Neither ketoconazole nor fluconazole were shown to affect the mRNA levels of steroidogenic enzymes or cell number; therefore; a single dose is unlikely to have a long-term effect (van der Pas et al. 2012).

\section{Metyrapone}

Metyrapone (SU-4885; Metopirone) inhibits 11 $\beta$-hydroxylase (Fig. 2) (Liddle et al. 1959) and 17 $\alpha-, 18-$, and 19hydroxylase (Table 4) (Gower 1974). Cortisol levels decrease after $2 \mathrm{~h}$ of the first dose (Verhelst et al. 1991). Doses range from $500 \mathrm{mg}$ to $4.5 \mathrm{~g} /$ day, or $6 \mathrm{~g} /$ day in divided doses (usually starting with $250 \mathrm{mg}$ four times daily, Table 3; Nieman 2002, Fleseriu 2012). Notably, and similar to ketoconazole, rapid uptitration of metyrapone is essential to achieve a full effect (Kamenicky et al. 2011, Castinetti et al. 2014). The strong cortisol-lowering effect of metyrapone can be accompanied by the loss of negative

Published by Bioscientifica Ltd 


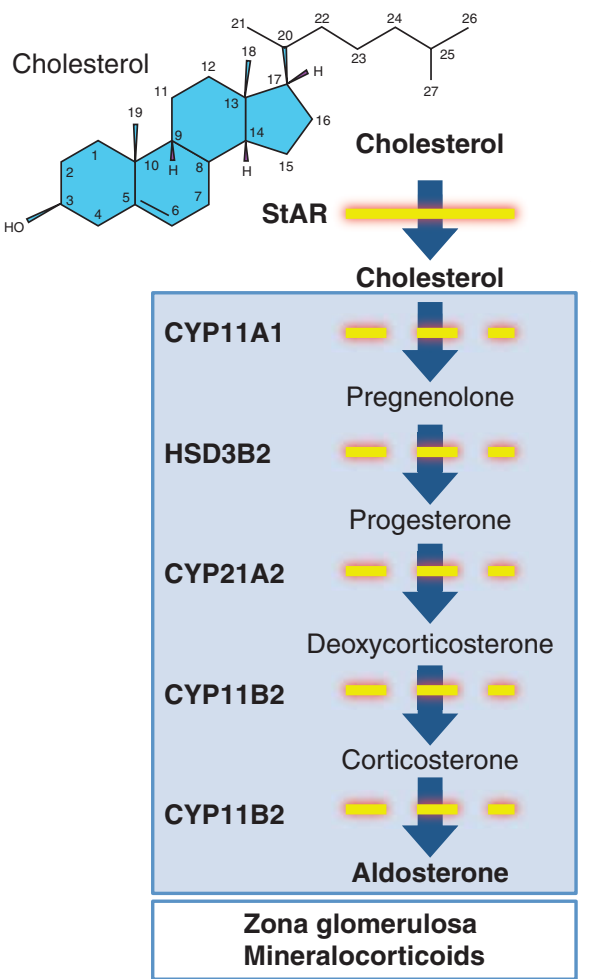

Figure 2

Adrenocortical steroidogenic pathways. A simplified diagram of adrenal steroidogenesis is depicted. Cushing's disease is almost always caused by a pituitary corticotrope adenoma that oversecretes corticotropin (ACTH). ACTH stimulates the adrenal gland to start steroid synthesis. After activation of MC2R by ACTH, the StAR protein is phosphorylated. Then, StAR facilitates cholesterol transport across the mitochondrial inner membrane. Cholesterol is the common precursor of the steroid molecules and, after several enzymatic reactions, is ultimately converted into

feedback and ACTH inhibition (Fig. 1). Increments in ACTH secretion may override steroidogenic blockade that may occur during the first month following initiation of treatment. Nevertheless, prolonged metyrapone activity in patients with $\mathrm{CD}$ has been shown, despite a rise in plasma ACTH levels (Verhelst et al. 1991). ACTH also overstimulates production of adrenal androgen and mineralocorticoid precursors (e.g. desoxycorticosterone). Moreover, aldosterone biosynthesis is more severely affected than that of cortisol (Gower 1974). Therefore, several side effects related to metyrapone treatment limit its clinical use in patients with $\mathrm{CD}$ (Table 3). However, combination therapy has been proposed to improve tolerance and increase efficacy (Table 5; Verhelst et al. 1991, Kamenicky et al. 2011). Despite safety concerns about the use of this drug in pregnant women, metyrapone has been used sporadically during pregnancy (Lindsay et al. 2005, Karaca et al. 2010). Additional long-term studies with metyrapone biologically active aldosterone, cortisol, or androstenedione that is further processed to testosterone in testicles. The zona glomerulosa, fasciculata, and reticularis are the three adrenal cortex histological zones, which synthesize steroid hormones with mineralocorticoid, glucocorticoid, or androgenic properties respectively. Enzyme nomenclature is given in detail in Table 1. CYP11A1, CYP11B1, and CYP11B2 are located in the mitochondria, and the remaining enzymes are located in the smooth endoplasmic reticulum.

in patients with $\mathrm{CD}$ are warranted. Currently, metyrapone has limited availability in most countries.

\section{Mitotane}

1-(o-Chlorophenyl)-1-( $p$-chlorophenyl)-2,2-dichloroethane (o, $\mathrm{p}^{\prime}$-DDD) (Lysodren; mitotane), an insecticide analog of dichlorodiphenyltrichloroethane has been extensively used to treat all forms of hypercortisolism (Boscaro et al. 2001). Mitotane's mechanism of action was initially described in animal studies as lipid accumulation and atrophy of fasciculate and reticularis regions of the adrenal cortex. Effects on the zona glomerulosa were only observed after prolonged therapy (Cueto \& Brown 1958). Within $12 \mathrm{~h}$ of treatment in dogs, electron microscopy revealed rupture of mitochondrial cristae, followed by mitochondrial swelling, lysis, and cell death (Miller \& Crapo 1993). Conversion of cholesterol to pregnenolone was markedly impaired indicating that 
Table 3 Doses and relevant side effects of drugs used in the medical treatment for Cushing's disease

$\begin{array}{ll}\begin{array}{l}\text { Steroidogenesis inhibitors } \\ \text { Ketoconazole } \\ \text { Fluconazole }\end{array} & 400-1200 \mathrm{mg} / \mathrm{day} \\ & 200 \mathrm{mg} / \mathrm{day} \\ \text { Metyrapone } & 0.5-4.5 \mathrm{~g} / \mathrm{day} \\ \text { Mitotane } & 2-5 \mathrm{~g} / \mathrm{day} \\ & \\ & \\ \text { Etomidate } & \text { Bolus } 0.03 \mathrm{mg} / \mathrm{kg} \text { i.v.; } \\ & \text { followed by } \\ & 0.1-0.3 \mathrm{mg} / \mathrm{kg} \text { per } \mathrm{h} \\ \text { LCl699 } & 4-100 \mathrm{mg} / \mathrm{day} \\ & \text { (investigational drug) } \\ \text { Centrally acting drugs } & 0.5-7 \mathrm{mg} / \mathrm{week} \\ \text { Cabergoline } \\ \text { Bromocriptine } & 1-30 \mathrm{mg} / \mathrm{day} \\ \text { Pasireotide } & 750-2400 \mu \mathrm{g} / \mathrm{day} \\ & \\ \text { Retinoic acid } & 10-80 \mathrm{mg} / \mathrm{day} \\ \text { Glucocorticoid receptor antagonist } & \\ \text { Mifepristone } & 300-1200 \mathrm{mg} / \mathrm{day}\end{array}$

Hepatitis, cholestasis, gynecomastia, gastrointestinal upset, edema, skin rash. Hypogonadism in men. Fluconazole may be better tolerated

Acne, hirsutism, lethargy, dizziness, ataxia, nausea, hypertensive crisis, hypokalemia, edema, and adrenal insufficiency

Gastrointestinal distress, impaired concentration and dizziness, gynecomastia, hepatitis, cholestasis, hyperlipidemia, prolongation of bleeding time, and adrenal insufficiency. Effect antagonized by spironolactone

Nephrotoxicity, sedation, pain at the infusion site, anaphylactic reactions, coughing, hiccups, nausea, vomiting, and myoclonus

Fatigue, nausea, headache, and hypokalemia

Nasal congestion, nausea, postural hypotension, and headache. Gradual increase minimizes side effects

Gastrointestinal-related conditions, hyperglycemia, cholelitiasis, nausea, abdominal pain, fatigue, headache, hypotension, and adrenal insufficiency

Xerophthalmia and arthralgias

Hypokalemia, worsening of hypertension, adrenal insufficiency, endometrial hyperplasia, fetal loss, gastrointestinal complaints, fatigue, nausea, headache, arthralgia, vomiting, and edema. Contraindicated in women planning pregnancy

Jeffcoate et al. (1977), Robinson et al. (1987), Verhelst et al. (1991), Castinetti et al. (2009), Fleseriu et al. (2012), Heyn et al. (2012), Nieman (2002), and Feelders \& Hofland (2013).

side-chain cleavage of cholesterol was the major enzymatic step affected inhibiting the cytochrome P450 enzymes CYP11A1 (mitochondrial side-chain cleavage enzyme), 11ß-hydroxylation (CYP11B1), and 18-hydroxylation (CYP11B2), and non-P450 enzymes (3ß-hydroxysteroid dehydrogenase) (Fig. 2; Miller \& Crapo 1993). Mitotane also stimulates CYP3A4 expression, reducing cortisol bioavailability (Kroiss et al. 2011). Therefore, mitotane has three effects: i) adrenocorticolytic, ii) modification of steroid metabolism, and iii) direct inhibition of steroid biosynthesis. Although used to treat adrenocortical carcinoma, mitotane has proven effective in patients with CD (Bledsoe et al. 1964, Baudry et al. 2012). Mitotane displays a relatively slow onset of action compared with other steroidogenesis inhibitors and saturation can be expected 2-3 months after initiation of therapy (Luton et al. 1979, Fleseriu \& Petersenn 2012). Overall, $80 \%$ of patients achieve normalization of urinary markers; however, 60\% relapsed after therapy withdrawal indicating a low level of adrenolytic action (Luton et al. 1979, Schteingart et al. 1980). Sustained remission after mitotane discontinuation has been reported in 30\% of patients measured at a mean follow-up of 37 months (Miller \& Crapo 1993). Doses are approximately $4 \mathrm{~g} /$ day, with a gradual increment from 0.5 to $1 \mathrm{~g} /$ day (Table 3; Luton et al. 1979). Results from a recent retrospective study revealed remission in 48 (72\%) out of 67 patients treated for long-term CD after a median of 6.7 (5.2-8.2) months (Baudry et al. 2012) at lower doses compared with adrenal cancer.

Despite its effectiveness, mitotane therapy is complicated by several side effects (Table 3 ). Owing to an accelerated metabolism of exogenous steroids, especially hydrocortisone, replacement doses must be increased to avoid adrenal crises (Robinson et al. 1987). Mitotane may lead to restoration of gonadal function and fertility; therefore, effective contraception is advisable for female patients (Miller \& Crapo 1993). Mitotane is stored in adipose tissue for 2 years after administration ends and should not be used in women considering pregnancy within 5 years of discontinuation (Leiba et al. 1989). Owing to the stimulatory effect of mitotane on cortisol-binding globulin levels (Nader et al. 2006), serum cortisol measurements are not useful and monitoring of urinary or serum free cortisol is the best index of response (Alexandraki et al. 2010). Replacement therapy requirements are higher than normal, due to interference of hormone-binding proteins as well. Mitotane combined with pituitary irradiation was

Published by Bioscientifica Ltd. 
Table 4 Enzymes that catalyze the initial reaction in the pathways of steroid hormone biosynthesis

\begin{tabular}{|c|c|c|}
\hline \multirow[b]{2}{*}{ Localization and common name } & \multicolumn{2}{|c|}{ Nomenclature $^{a}$} \\
\hline & Previous & Current \\
\hline \multicolumn{3}{|l|}{ Mitochondrial } \\
\hline StAR protein & StAR & StAR \\
\hline $\begin{array}{l}\text { Side-chain cleavage (scc) } \\
\text { enzyme or } 20,22 \text { desmolase }\end{array}$ & P450scc & CYP11A1 \\
\hline $11 \beta$-hydroxylase & P450 C11 & CYP11B1 \\
\hline $\begin{array}{l}\text { Aldosterone synthase, } \\
\text { 18-hydroxylase }\end{array}$ & P450 C11AS & CYP11B2 \\
\hline \multicolumn{3}{|l|}{ Smooth endoplasmic reticulum } \\
\hline $\begin{array}{l}\text { 17 } \beta \text {-hydroxysteroid dehydro- } \\
\text { genase, } 3 \beta \text {-hydroxysteroid } \\
\text { dehydrogenase }\end{array}$ & $3 \beta-H S D$ & $3 \beta-H S D$ \\
\hline $17 \alpha$-hydroxylase/17,20 lyase & P450 C17 & CYP17 \\
\hline 21-Hydroxylase & P450 C21 & CYP21A2 \\
\hline Aromatase & P450 aro & CYP19 \\
\hline
\end{tabular}

\begin{tabular}{l} 
Inhibitors \\
\hline Imidazoles $^{\mathrm{b}}$ \\
Imidazoles \\
Etomidate \\
Mitotane \\
Aminoglutethimide \\
Imidazoles \\
Mitotane \\
Aminoglutethimide \\
Metyrapone \\
Mitotane \\
LCl699 \\
Aminoglutethimide \\
Metyrapone \\
Trilostane \\
Imidazoles \\
Aminoglutethimide \\
Metyrapone \\
Aminoglutethimide \\
Aminoglutethimide
\end{tabular}

References
Walsh et al. (2000)
Camacho et al. (1967), Schulte et al.
(1990), and Miller \& Crapo (1993)
Camacho et al. (1967), Gower (1974),
Feldman (1986), Loli et al. (1986),
and Miller \& Crapo (1993)
Camacho et al. (1967), Gower (1974),
Miller \& Crapo (1993), and Calhoun
et al. (2011)
Potts et al. (1978), Dewis et al. (1983),
and Engelhardt \& Weber (1994)
Camacho et al. (1967), Gower (1974),
Feldman (1986), Loli et al. (1986),
and Miller \& Crapo (1993)
Camacho et al. (1967)
Camacho et al. (1967)

${ }^{\text {a }} 450$ scc or CYP11A1, i.e. gene family 11 , subfamily A, polypeptide 1.

${ }^{\mathrm{b}}$ Imidazoles=ketoconazole, fluconazole, econzale, and/or miconazole.

shown to be efficacious in non-controlled clinical trials (Luton et al. 1979, Schteingart et al. 1980).

\section{Etomidate}

The imidazole anesthetic agent etomidate (Amidate or Hypnomidate) was observed to decrease postoperative cortisol values in patients during anesthesia (Feldman 1986). Subsequently, it was discovered that etomidate inhibits the 11ß-hydroxylase enzyme (CYP11B1), 17 $\alpha$-hydroxylase (CYP17A1), and the cholesterol side-chain cleavage complex (P450scc, or CYP11A1, or 20,22 desmolase), thus blocking multiple steps of steroidogenesis (Fig. 2). It is the only parenteral steroidogenesis inhibitor available and provides rapid hypercortisolemia control (Allolio et al. 1988, Schulte et al. 1990). An i.v. bolus injection of etomidate at a low non-hypnotic dose $(0.03 \mathrm{mg} / \mathrm{kg})$ followed by constant infusion of $0.3 \mathrm{mg} / \mathrm{kg}$ per $\mathrm{h}$ for $24 \mathrm{~h}$ (Table 3) decreases serum cortisol in a dose-dependent manner with significant suppression after the first $5 \mathrm{~h}$ with a maximum effect after $11 \mathrm{~h}$ (Allolio et al. 1988, Schulte et al. 1990). Glucocorticoid replacement to prevent adrenal insufficiency is warranted after $24 \mathrm{~h}$ of etomidate infusion. Clinical use of etomidate in CS has been limited by sedative side effects, but could be safe and effective in significant biochemical disturbance, sepsis, severe psychosis, and in preoperative instability (Heyn et al. 2012, Preda et al. 2012).

\section{LCI699}

First characterized as an aldosterone biosynthesis inhibitor for primary aldosteronism and essential hypertension, LCI699 is an 18-hydroxylase (aldosterone synthase) inhibitor blocking the conversion of hydroxycorticosterone to aldosterone. It also inhibits $11 \beta$-hydroxylase (CYP11B1) in a similar manner to the R-enantiomer of fadrozole (FAD286) that blocks the hydroxylation of deoxycortisol to cortisol as well as CYP11B2 blocking the conversion of deoxycorticosterone to corticosterone (Fig. 2) (Calhoun et al. 2011). LCI699 is currently under investigation as a treatment for CD (Tritos et al. 2011, Feelders \& Hofland 2013). In a phase II proof of concept study of LCI699, rapid UFC normalization in 11 out of 12 patients with $\mathrm{CD}$, all achieving $>50 \%$ reduction in baseline UFC, was observed. Doses ranged from 4 to $100 \mathrm{mg} /$ day for 10 weeks (Bertagna et al. 2014). As expected, ACTH increased; $45 \%$ of cases had ACTH more than twice that of baseline. Most adverse events were mild or moderate (Table 3). Based on these promising results, a larger phase III trial is awaited. 
Table 5 Overview of agents that have been tested as combination drug therapy for Cushing's disease. Doses: cabergoline from 0.5 to $3 \mathrm{mg} /$ week, ketoconazole 200 to $1200 \mathrm{mg} /$ day, pasireotide 300 to $750 \mu \mathrm{g} /$ day, mitotane 3 to $5 \mathrm{~g} /$ day, metyrapone 3 to $4.5 \mathrm{~g} / \mathrm{day}$, and octreotide 300 to $1500 \mu \mathrm{g} / \mathrm{day}$. The studies are described in the text

\begin{tabular}{|c|c|c|c|c|}
\hline \multirow[b]{2}{*}{ References } & \multirow[b]{2}{*}{ Compounds } & \multirow[b]{2}{*}{ Patients $(n)$} & \multicolumn{2}{|c|}{ UFC normalization (\%) } \\
\hline & & & Monotherapy & Combination \\
\hline Barbot et al. (2014) & Ketoconazole + cabergoline & 14 & $20-30$ & 80 \\
\hline Feelders et al. $(2010 b, c)$ & Pasireotide + cabergoline + ketoconazole & 17 & 30 & $\begin{array}{c}50 \mathrm{P}+\mathrm{C} \\
90 \mathrm{P}+\mathrm{C}+\mathrm{K}\end{array}$ \\
\hline Vilar et al. (2010) & Cabergoline + ketoconazole & 12 & 25 & 70 \\
\hline Total/average & - & 43 & 27 & 73 \\
\hline \multicolumn{5}{|c|}{ Severe hypercortisolism/aggressive tumor } \\
\hline Vignati \& Loli (1996) & Ketoconazole + octreotide & 4 & 0 & 0 \\
\hline Bode et al. (2010) & Temozolomide + pasireotide & 1 & 0 & 100 \\
\hline Kamenicky et al. (2011) & Mitotane + metyrapone + ketoconazole & $11 \mathrm{CS}(4 \mathrm{CD})$ & 0 & 100 \\
\hline Total/average & - & 16 & 0 & 66 \\
\hline
\end{tabular}

UFC, urinary free cortisol.

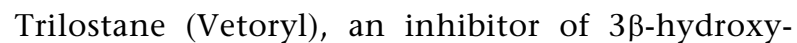
steroid, was withdrawn from human use in the USA in 1994 (Potts et al. 1978, Dewis et al. 1983, Engelhardt \& Weber 1994). Aminoglutethimide (Cytadren; Camacho et al. 1967, Misbin et al. 1976) is rarely used in the treatment of patients with $\mathrm{CD}$. The mechanisms of action, common doses, and main adverse effects of aminoglutethimide are listed in Tables 2 and 3.

\section{Centrally acting drug treatments}

Human corticotrope adenomas display responsiveness to neurohumoral influences such as dexamethasone suppression, lysine vasopressin, thyrotropin-releasing hormone, and metyrapone administration. Dexamethasone is a synthetic glucocorticoid extensively used to demonstrate the sensitivity of HPA axis negative feedback to glucocorticoids for differential diagnosis of CS. If the HPA axis is normal, any supraphysiological dose of dexamethasone is sufficient to suppress pituitary ACTH secretion. ACTH secretion can also be suppressed in most patients with $C D$ as pituitary corticotrope adenomas are only relatively resistant to inhibition of glucocorticoid negative feedback. Hypophyseal ACTH secretion can be influenced by serotonin antagonists, dopamine or gamma-amino butyric acid (GABA) agonists, somatostatin receptor ligands (SRLs), retinoic acid, and temozolomide (Fig. 1). In addition to biochemical effects, CD has been associated with periodic hormonogenesis (cyclical CD) or spontaneous remission, indicating that some cases of $\mathrm{CD}$ may be due to altered neuroregulatory influences (Van Cauter \& Refetoff 1985, Dickstein et al. 1991, Colao et al. 1997, Nieman 2002).

\section{Somatostatin receptor ligands}

Somatostatin Somatostatin (SST) is a cyclic peptide with a circulating half-life of $<3$ min (Brazeau et al. 1973). The name SST originates from a supposed 'specific' function as an inhibitor of somatotropin (growth hormone $(\mathrm{GH})$ ) release, thus somatotropin release-inhibiting factor. In the CNS, SST has a key inhibitory action in the secretion of GH (Brazeau et al. 1973), prolactin (PRL; Vale et al. 1974), thyrotropin (Siler et al. 1974), and ACTH (Richardson \& Schonbrunn 1981, Lamberts et al. 1989a,b) from the anterior pituitary gland. At the peripheral nervous system level, SST plays a regulatory role in the gastrointestinal tract inhibiting flow from the gallbladder, bowel motility and gastric emptying, smooth muscle contraction, and nutrient absorption from the intestine as well as in the exocrine pancreas. SST also inhibits the release of glucagon (Boden et al. 1986), insulin (Alberti et al. 1973), and pancreatic polypeptide (Koerker et al. 1974).

SST exerts action through five $G$ protein-coupled receptor subtypes: SSTR1-SSTR5 (Batista et al. 2006, Ben-Shlomo et al. 2010, Cuevas-Ramos \& Fleseriu 2014). The majority of corticotrope adenomas (>85\%) express SSTR2 and SSTR5 mRNA, and to a lesser extent SSTR1 (63\%) (Miller et al. 1995). The membrane density of SSTR subtypes, particularly SSTR2, is affected by hypercortisolism (Schonbrunn 1982, Stalla et al. 1994, de Bruin et al. 2009). In contrast, SSTR5 expression appears to be relatively unaffected by high cortisol levels. Therefore, in patients with active CD, SSTR5 is predominantly expressed compared with SSTR2 (de Bruin et al. 2009).

Somatostatin receptor ligands The potent antisecretory properties of SST have made it an important

Published by Bioscientifica Ltd 
pharmacological target for hormonal hypersecretion treatment. However, its short half-life, the multiple and simultaneous actions in different organs, and the need for parenteral administration hampered its clinical use. SRLs have originated after manipulation of SST key structural characteristics, which allowed several reductions of the above disadvantages. Recently, an update on SRLs and SRL's resistance has been published (Cuevas-Ramos \& Fleseriu 2014).

Octreotide and lanreotide are SSTR2 SRLs with low activity in suppressing ACTH in patients with CD (Lamberts et al. 1989a,b, Biller et al. 2008). After eucortisolemia restoration, SSTR2 expression recovers, becoming similarly abundant to SSTR5, thus improving treatment responsiveness (Feelders et al. 2010a, van der Pas et al. 2013). The SSTR2 mRNA expression, however, did not correlate with protein levels. The discrepancy between mRNA and protein levels may be caused by persistent cortisol-induced disturbed translation of SSTR2 mRNA and GR on the adenoma cells still exposed to sufficiently high levels of circulating cortisol to suppress the transcription/ translation of the SSTR2 gene (van der Pas et al. 2013). The recovery of SSTR2 expression may have therapeutic implications, as it may allow sequential treatment with SSTR2 ligands after induction of partial or complete remission with other drugs. Nevertheless, the predominant expression of SSTR 5 mRNA in cultured human corticotrope adenoma cells prompted an alternative approach using a SSTR5 ligand (Batista et al. 2006).

\section{Pasireotide}

Pasireotide (SOM230; Signifor) is an SRL that principally binds to SSTR5, in addition to SSTR1, SSTR2, and SSTR3 (Ben-Shlomo et al. 2010). Pasireotide has a 40-fold higher affinity for SSTR 5 than octreotide (Murray et al. 2004). After pasireotide treatment, in primary cultures of human corticotrope tumors, cell proliferation and ACTH secretion were suppressed (Batista et al. 2006). Notably, dexamethasone pre-treatment did not reduce cell sensitivity to pasireotide, indicating that SSTR5 is resistant to negative control by glucocorticoids (Hofland et al. 2005). Moreover, SSTR2 mRNA expression was reduced after dexamethasone treatment, whereas SSTR5 mRNA was not significantly affected (van der Hoek et al. 2005). As pituitary corticotrope ACTH-secreting adenomas predominantly express SSTR5, results obtained using primary cell cultures (Hofland et al. 2005, Batista et al. 2006), animal models (Silva et al. 2005, Ben-Shlomo et al. 2010), and clinical studies have confirmed ACTH suppression after pasireotide treatment.
Overexpression of SSTR2 or SSTR5 in mouse AtT20 corticotrope adenoma cells resulted in pasireotide suppressive effects through SSTR5 but not SSTR2 (Ben-Shlomo et al. 2009). In a phase II study, proof-of-concept, open-label, single-arm, and multicenter study, using s.c. pasireotide at $600 \mu \mathrm{g}$ twice a day for 15 days, patients who displayed normalized UFC levels with pasireotide treatment showed a 1.8-fold higher plasma concentration and 1.3-fold higher plasma exposure in comparison with non-responders, indicating that the clinical response required a plasma pasireotide level above a certain threshold for an optimal response (Boscaro et al. 2009). A subsequent doubleblinded, randomized, multicenter phase III trial with pasireotide 600-900 $\mu \mathrm{g}$ twice a day revealed UFC reduction in most patients (Colao et al. 2012) and normalization in approximately one-quarter of patients. The rate of UFC normalization was higher $(\sim 50 \%)$ in patients with mild CD. Responders can be identified within approximately 2 months of treatment (Colao et al. 2012). Serum and salivary cortisol and plasma ACTH levels were also reduced with notable clinical improvement including blood pressure, lipids, and quality of life (Colao et al. 2012). An interesting observation that warrants further investigation is the reduction in tumor volume after 12 months of high-dose pasireotide ( $900 \mu \mathrm{g}$ twice daily) treatment in patients with CD (Colao et al. 2012).

Except for a higher degree and frequency of hyperglycemia, adverse effects are similar to those of other SRLs (Table 3). Hyperglycemia-related adverse events occurred in $73 \%$ of patients and $6 \%$ of patients discontinued the study treatment because of such events. Glucose and HbA1c levels increased soon after the initiation of treatment with pasireotide, necessitating the administration of medications to manage these complications. Of the patients who did not have diabetes at baseline $48 \%$ had a HbA1c level of $6.5 \%$ or more at the end of the study.

The mechanism of pasireotide-induced hyperglycemia in healthy volunteers is mediated by incretin hormone, glucagon-like peptide 1 (GLP1) and gastric inhibitory polypeptide, reduction and therefore insulin secretion decline. Glucagon secretion, however, seems to be mildly inhibited (Henry et al. 2011). A dipeptidyl peptidase 4 inhibitor or a GLP1 agonist was shown to be particularly effective in countering increased glucose levels in healthy volunteers; however, further studies in CD are required (Henry et al. 2011, Colao et al. 2014).

The absence of expression of SSTR 5 mRNA in $40 \%$ of ACTH-secreting pituitary adenomas (de Bruin et al. 2009) might explain the different responses to pasireotide. It remains to be determined whether any correlation exists

Published by Bioscientifica Ltd. 
between the degree of SSTR2/SSTR5 receptor expression and the in vivo response to pasireotide in patients with CD.

Pasireotide was approved (in the USA and in Europe) for the treatment of patients with $\mathrm{CD}$ for whom surgery has failed or is not possible (Fleseriu \& Petersenn 2012, Feelders \& Hofland 2013, Colao et al. 2014).

Additionally, somatropim (DG3173) is a novel SRL that selectively binds SSTR2, SSTR4, and SSTR5. It has a well-demonstrated effect in GH suppression (Plöckinger et al. 2012, Fleseriu \& Petersenn 2013). Further research is necessary to evaluate the effects on ACTH.

\section{Dopamine agonists}

Dopamine is the main catecholamine neurotransmitter in the human brain involved in the regulation of locomotor activity, food intake, and endocrine function (Missale et al. 1998). The dopamine receptor (DR) family consists of five receptor subtypes, two with preferentially stimulatory effects (D1 and D4) and three with inhibitory properties (D2, D3, and D5) (Missale et al. 1998). D2 (DRD2) and, to a lesser extent, D4 (DRD4) are the DR subtypes that are expressed in the anterior pituitary gland. The $\mathrm{D} 2$ subtype has a long (D2long) and a short (D2short) isoforms and both variants are expressed in lactotrope and melanotrope cells (Pivonello et al. 2004). Inhibition of PRL secretion is the most well-known action of dopamine in the anterior pituitary. However, results of recent studies have indicated that the D2 receptor is expressed in $80 \%$ of corticotrope adenomas (Lamberts et al. 1980, Pivonello et al. 2004, Gatto \& Hofland 2011). The $D 2$ receptor is not negatively regulated by cortisol (de Bruin et al. 2009). Consistently, dopamine agonists, bromocriptine, and cabergoline have shown inhibitory effects in vitro on ACTH secretion in corticotrope tumor cells (Pivonello et al. 2004) and apoptosis in an ACTHsecreting mouse cell line; therefore, in vivo effectiveness can also be suspected (Lamberts et al. 1980, Yin etal. 1994). In the pituitary gland, pro-opiomelanocortin (POMC) is cleaved by prohormone convertases (PCs) 1 and 2 (Bertagna 1994). PC1 (PCSK1) is expressed in both the anterior and intermediate pituitary lobes, whereas PC2 (PCSK2) expression is restricted to the intermediate lobe, which is believed to regress soon after birth and, therefore, is absent in adults (Bertagna 1994, Iino et al. 2010). Lamberts and colleagues showed that $\mathrm{D} 2$ receptor agonist-responsive tumors located in the region consisted of basophilic adenomatous tissue or multiple microadenomas accompanied by hyperplastic cell nests (Lamberts et al. 1980, 1982). PC2 expression at the intermediate lobe, and the phosphorylation of its cellsignaling molecule Akt, have been identified as clinical markers of an increased rate of tumor growth in CD (Iino et al. 2010). Compared with corticotrope pituitary tumors that were histologically classified as pure adenomas, tumors identified as adenomatous hyperplasia or hyperplasia of ACTH-producing cells have higher PC2 expression and, although not statistically significant, higher neurofilament (NF) protein expression. Together, these results led to the hypothesis that CD may originate not only from corticotrope adenomas of the anterior lobe, but also from an adenoma or adenomatous hyperplasia of ACTH-producing cells of the intermediate zone because the PC2 enzyme is predominantly expressed in this region of the pituitary gland (Iino et al. 2010). In addition, increases in the levels of alpha-melanocyte-stimulating hormone, which is a PC2 processing product, in the inferior petrosal sinus were higher in these patients. Finally, increased NF expression indicates close proximity of these lesions to the posterior pituitary lobe. PAX7, a protein restricted to the melanotrope lineage of the intermediate pituitary lobe that is not expressed in the anterior corticotrope cells, was identified as a key regulator that drives POMC-positive pituitary cells toward melanotrope differentiation (Budry et al. 2012). In the intermediate lobe, cells of rat pituitary glands lacking PAX7 showed downregulation of melanotrope-specific genes (e.g. POMC, $P C 2$, and D2R (DRD2)) and these cells switched towards the corticotrope lineage. Similar observations were made using AtT20 mice corticotrope adenoma cells (Budry et al. 2012). The hypothesis that adenomatous hyperplasia or corticotrope hyperplasia is particularly sensitive to dopamine D2 receptor agonists (Lamberts et al. 1982), and SSTR5 expression appears to be lower than that in the pure adenomas awaits further confirmation (Budry et al. 2012).

\section{Cabergoline}

Cabergoline (Caberlin, Dostinex, or Cabaser) is a D2 receptor agonist, currently approved in the USA to treat hyperprolactinemia. It has a long half-life and a very high affinity and specificity for $\mathrm{D} 2$ receptors. Cabergoline has been evaluated as a potential therapy in patients with $\mathrm{CD}$ who have failed surgery (de Bruin et al. 2009). Initial response is up to $75 \%$ (Pivonello et al. 2009); however, $30-40 \%$ of these patients will have a sustained response over a 2 -year period (Pivonello et al. 2009, Lila et al. 2010). A retrospective study reported complete response to cabergoline therapy in $37 \%$ of cases using an initial dose of $0.5-1 \mathrm{mg} /$ week with a further increment up to $6 \mathrm{mg} /$ week. At a mean dose of $2.1 \mathrm{mg} /$ week, $30 \%$ (nine out of 30 cases) persisted with sustained control after 3 years (Godbout et al. 2010). Acute cabergoline response does not predict long-term disease control.

Published by Bioscientifica Ltd 
Approximately $25 \%$ of patients present with cabergoline escape phenomenon at 2-5 years. Doses range from 0.5 to $7.0 \mathrm{mg} /$ week (median $3.5 \mathrm{mg}$ ) raising potential concerns about long-term safety (Table 3). By activating valvular fibroblasts through serotonin receptor $2 \mathrm{~B}$, valve calcification was observed in patients with prolactinomas treated with cabergoline. However, this finding was not associated with cardiac valve dysfunction after 2 years of follow-up (Delgado et al. 2012). Long-term studies, however, are required to elucidate potential cardiac involvement at long-term high doses.

\section{Bromocriptine}

The effectiveness of bromocriptine (Parlodel, Cycloset, or Brotin) was initially reported in small studies of patients with CD (Lamberts \& Birkehager 1976, Miller \& Crapo 1993). Out of 23 patients with CD treated with $1.25-30 \mathrm{mg} /$ day for 3-180 weeks, approximately $40 \%$ achieved urinary or plasma glucocorticoid levels normalization, and ACTH levels decreased by more than 50\% in $20 \%$ of patients (Table 3; Miller \& Crapo 1993). Subsequent consecutive studies on the effects of bromocriptine in patients with $\mathrm{CD}$ have not confirmed relevant efficacy (Biller et al. 2010).

\section{Chimeric compounds}

Corticotrope cells coexpress both SSTRs and D2 receptors, which work synergistically through membrane interaction or dimerization (Fig. 3; Rocheville et al. 2000, Ren et al. 2003, de Bruin et al. 2009). Studies on different tumor models, including pituitary adenomas, revealed a higher potency of BIM-23A779, BIM-23A760, and BIM-23A781 (chimeric molecules containing both SST and dopamine structural elements) in controlling tumor cell growth (Ferone et al. 2013). Further studies of patients with CD are required.

\section{Retinoic acid}

Retinoic acid type II nuclear receptors are important drug targets for cancer therapy. In animal studies and in vitro experiments, an effective inhibitory effect has been shown on corticotrope tumor growth, $P O M C$ transcription, plasma ACTH, and corticosterone secretion from human ACTHsecreting pituitary tumors, but not in normal cells (Fig. 1). Retinoic acid also increased caspase-3-activity-induced cell death (Labeur et al. 2009). Retinoic acid exhibits peripheral activity at the level of the adrenal and induced bone morphogenetic protein 4 (BMP4), a member of the transforming growth factor beta superfamily that plays a central role during pituitary organogenesis and transcription (Labeur et al. 2009). The antiproliferative action of retinoic acid is considered to be mediated by BMP4. Such preliminary results promoted a randomized treatment with retinoic acid vs ketoconazole in dogs with CD (Labeur et al. 2009). Recently, seven patients with CD were treated with $10-80 \mathrm{mg}$ of retinoic acid in a longitudinal, non-controlled, non-randomized, multicenter study (Pecori Giraldi et al. 2012). After 6-12 months, three patients displayed normalized UFC with mild adverse effects (Table 3). These results need further confirmation in larger studies.

\section{Temozolomide}

Temozolomide (Temodar, Temodal, or Temcad) is an orally administrated second-generation alkylating chemotherapeutic agent. It is a methyl-triazenoimidazolecarboxamide derivative that methylates DNA at the $O 6$ position of guanine causing a mismatch with thymine during the next DNA replication cycle, leading to cell apoptosis (Fig. 1). Drug efficacy relies on O6-methylguanine-DNA methyltransferase (MGMT) enzyme activity. MGMT reverses alkylation, and it has been initially suggested that low MGMT expression could predict a better response to temozolomide. After treatment with temozolomide, tumors become soft and friable, and display better differentiation, less mitoses, and a lower $\mathrm{Ki}-67$ index, indicative of surgical benefits as well as a reduction in cell proliferation (Syro et al. 2011). Temozolomide could be an efficacious drug in cases of aggressive $\mathrm{CD}$, but the predictive role of MGMT expression remains to be determined (Syro et al. 2011, Dillard et al. 2011).

\section{Cyproheptadine}

Cyproheptadine (Periactin or Peritol) has anti-serotonergic, anti-histaminic, and anti-cholinergic properties, and it has been studied for treatment of CD and Nelson's syndrome since 1975 (Krieger et al. 1975, Nieman 2002, Fleseriu 2012). In normal subjects, cyproheptadine may alter the feedback regulation of ACTH to different stimuli such as metyrapone and insulin-induced hypoglycemia (Cavagnini et al. 1975). These responses are independent of the effects on basal ACTH levels, and patients treated with cyproheptadine therapy have documented normalization of low-dose dexamethasone suppression, metyrapone response, insulin tolerance test, CRH response, and diurnal cortisol patterns (Ferrari et al. 1977). It has been postulated that ACTH secretion was

Published by Bioscientifica Ltd 


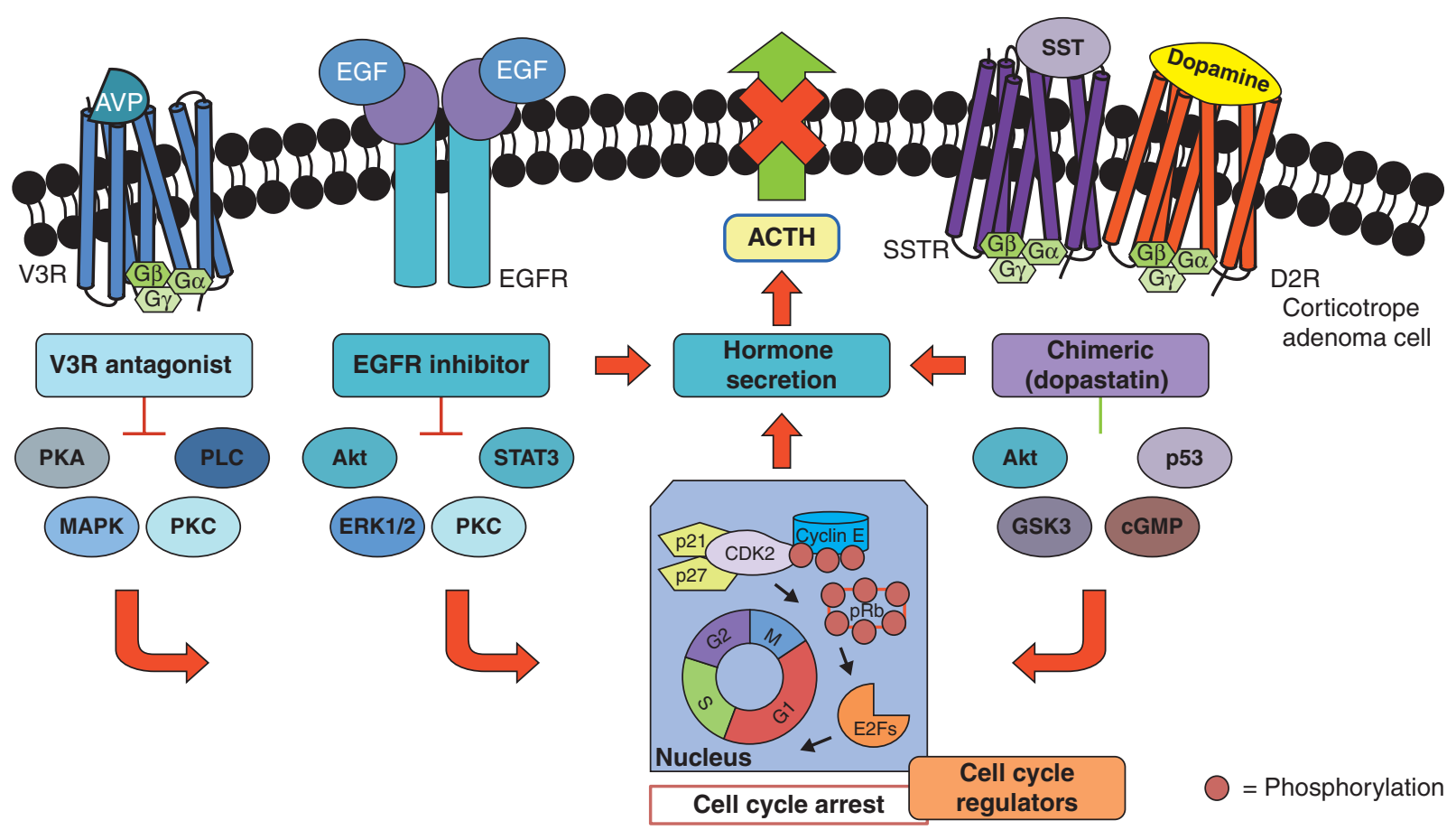

\section{Figure 3}

Potential novel therapeutic targets for CD. From left to right; the effect of V3 receptor-specific antagonists that could lead to a new class of agents that can suppress ACTH secretion in corticotrope adenomas (Ferone et al. 2013). After blocking of EGFR, a tyrosine kinase receptor, POMC expression is attenuated, and inhibition of corticotrope cell proliferation and apoptosis can be induced (Fukuoka et al. 2011). Through membrane interaction or dimerization (Rocheville et al. 2000), the G-protein-coupled somatostatin receptor (SSTR) and dopamine D2 receptor (D2R) have a synergistic effect on controlling tumor cell growth and ACTH secretion (de Bruin et al. 2009, Ferone et al. 2013). The main proteins of each receptor

also under serotoninergic control and a direct inhibitory effect on CRH and arginine vasopressin (AVP) secretion from the hypothalamus has been confirmed (Suda et al. 1983). However, clinical studies showed disappointing results (Nieman 2002, Biller et al. 2008). Control of CD activity with cyproheptadine has been described in case reports (Tanakol et al. 1996) at doses varying from 12 to $24 \mathrm{mg} /$ day. Main side effects are somnolence, hyperphagia, and weight gain. Other serotonin antagonists, metergoline, ketanserine, and ritanserine, have been evaluated in very few patients with limited results (Cavagnini et al. 1975, Sonino et al. 1992, Miller \& Crapo 1993).

\section{Valproic acid (valproate)}

The neurotransmitter GABA has an inhibitory effect on ACTH release (Maraka \& Stark 1974). GABA inhibits the functioning of the HPA axis in vivo, reducing CRH levels in hypophyseal portal blood after i.c.v. administration signaling pathway are depicted. The leading effect of such pathways is cell cycle arrest with a decrease in tumor growth. Interestingly, using a cyclindependent kinase 2 (CDK2)/cyclin E inhibitor in animal models, the ACTH and corticosterone levels were suppressed, and xenografted pituitary tumor growth was restrained (Liu et al. 2011b). Red lines/arrows indicate inhibition, whereas green lines/arrows indicate induction. PKA, protein kinase $A$; PLC, phospholipase C; PKC, protein kinase $C$; Akt, protein kinase $B$; ERK, extracellular signal-regulated kinases; GSK3, synthase kinase 3 beta; $\mathrm{Rb}$, retinoblastoma protein; E2F, E2 transcription factors.

(Fig. 1; Plotsky et al. 1987). Valproic acid (sodium valproate or valproate) is an antiepileptic agent that inhibits GABA aminotransferase. Patients with seizures treated with valproate showed suppression of ACTH. Valproate blocks GABA reuptake enhancing GABA inhibition of hypothalamic CRH release. Clinical reports of valproate-responsive patients with $\mathrm{CD}$ have emerged (Cavagnini et al. 1984, Koppeschaar et al. 1986, Colao et al. 1997). However, chronic administration and placebo-controlled studies failed to confirm the ACTHlowering effects of valproate (Reincke et al. 1988, Colao et al. 1997).

\section{Peroxisome proliferator-activated receptor gamma ligands}

Peroxisome proliferator-activated receptor gamma $(\operatorname{PPAR} \gamma)$ is a nuclear receptor that functions as a transcription factor. It is highly expressed in 
ACTH-secreting adenomas (Heaney 2004, Mannelli et al. 2010). PPAR $\gamma$ ligands, thiazolidinediones, have been shown to increase insulin sensitivity and also inhibit the growth of many tumors, including breast, colon, and prostate cancer cells (Mannelli et al. 2010). In addition, antiproliferation with G0/G1 cell cycle arrest, and apoptotic effects in murine cell model of corticotrope adenoma cells and inhibition of POMC transcription were demonstrated using PPAR $\gamma$ ligands (Heaney et al. 2002). However, the antiproliferative effects were observed at very high doses. The PPAR $\gamma$ agonist rosiglitazone was evaluated as a possible therapy for patients with CD. Despite initial results indicating that rosiglitazone could be an effective treatment for patients with CD (Ambrosi et al. 1990), further reports confirmed that PPAR $\gamma$ ligands have no efficacy (Kreutzer et al. 2009), a sustained ACTH decrease is rare, and ACTH levels may rebound (Suri \& Weiss 2005, Morcos et al. 2007). Current information is insufficient to support the routine clinical use of rosiglitazone or pioglitazone in patients with CD (Biller et al. 2008, Mannelli et al. 2010). Moreover, side effects such as edema, hypertension, weight gain, somnolence, hirsutism, and bruisability are significant, and there have also been concerns related to possible increased cardiovascular disease risks (Nissen \& Wolski 2010).

\section{Alpha 1 adrenergic receptor antagonists}

Alpha 1 adrenergic receptor antagonists have been suggested as a novel therapy for pituitary adenomas (Fernando \& Heaney 2005). In murine pituitary tumor cells, doxazosin (Cardura, Cardura XL) reduced phosphorylated retinoblastoma protein levels and induced G0-G1 cell cycle arrest with decreased tumor growth and reduced plasma ACTH levels (Fernando \& Heaney 2005). Further research is required to support the observations.

\section{GR antagonism}

As almost every human cell expresses GRs, conditions with glucocorticoid excess, such as $\mathrm{CD}$, result in the deleterious effects on cell metabolism. Therefore, blocking GRs seem to be a promising and attractive approach to treat CD. GRs are classically classified as type I with mineralocorticoid effects and type II with glucocorticoid effects. GR protein is encoded by the NR3C1 gene, which is located on chromosome 5 (5q31). Two isoforms of the GR have been identified, GR $\alpha$ and GR $\beta$ (Bamberger et al. 1996).

\section{Mifepristone}

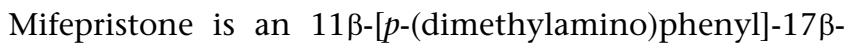
hydroxy-17-(1-propynyl)estra-4,9-dien-3-one competitive antagonist of androgen, progestin, and GRs (Bertagna et al. 1984, Bertagna et al. 1986). Mifepristone is the first potent glucocorticoid antagonist available for clinical use, which has affinity for GRs and very little agonist effect (Fig. 1). In normal subjects, mifepristone inhibits dexamethasone suppression and raises endogenous cortisol and ACTH values (Bertagna et al. 1984). It has been suggested that mifepristone may upregulate SSTR2 on corticotrope adenomas, which may then be treated with a SSTR2 ligand (octreotide or lanreotide; de Bruin et al. 2012). Symptomatic improvement was reported at doses of $5-20 \mathrm{mg} / \mathrm{kg}$ per day (Nieman et al. 1985), including prompt reversal of neuropsychiatric symptoms (Van der Lely et al. 1991, Johanssen \& Allolio 2007). Early in the 2000s, a few patients with CS had been treated with mifepristone and the first patient with CD was treated with mifepristone in 2001 (Chu et al. 2001). Results of further studies of treatment of additional CD cases with mifepristone confirmed clinical improvement (Castinetti et al. 2009). In a large prospective study (Fleseriu 2012), mifepristone showed clinical efficacy at doses of $300-1200 \mathrm{mg} /$ day (mean $900 \mathrm{mg}$ ) for over 6-4 months (Table 3). Diabetes control improved significantly, with reduction in the mean HbA1c (7.4-6.3\%) in addition to an overall decrease in antidiabetic medications (Fleseriu et al. 2012). Body weight and waist circumference also improved significantly after 24 weeks and mean percentage total body fat also declined. As a result of the mechanism of action, cortisol concentrations (up to sevenfold) and ACTH (up to twofold) tend to increase (Sonino \& Boscaro 1999, Fleseriu et al. 2012). Side effects are described in Table 3 (Fleseriu 2012). The authors of the main study concluded that the drug had an acceptable benefit-risk profile (Fleseriu 2012, Fleseriu \& Petersenn 2013). Nevertheless, some physicians consider mifepristone use only in specific situations such as in patients with severe hypercortisolism, when the chance of surgical cure is low, and in those waiting for the maximal efficacy of radiotherapy (Castinetti et al. 2009, Feelders \& Hofland 2013). The development of a selective GR without antiprogestin effects could also represent an important step in the long-term treatment of women with CD. Mifepristone should not be administered with drugs that are metabolized by CYP3A or CYP2C (e.g. simvastatin, cyclosporine, fentanyl, ciprofloxacin, non-steroidal anti-inflammatory drugs, and warfarin) because of an increased toxicity risk (Fleseriu \& Petersenn 2013). In the USA, in 2012,

Published by Bioscientifica Ltd. 
mifepristone (Korlym) was FDA approved for the treatment of glucose intolerance or diabetes in patients with CS.

\section{Mechanistic approach for combination therapy}

Combination medical therapy is an option that is gaining momentum and increased attention (Feelders et al. 2010b,c, Vilar et al. 2010, Kamenicky et al. 2011). It is possible that drug doses may be decreased with fewer adverse events and synergistic or additive effects on ACTHsecretion inhibition (Sonino \& Boscaro 1999, Feelders \& Hofland 2013) are possible; however, there is no treatment strategy valid for all cases (Table 5). Owing to coexpression of SSTR2 and D2 receptor that frequently occurs in corticotrope pituitary adenomas (Fig. 3), there is a rationale for treating patients with $\mathrm{CD}$ with a combination of drugs that target these receptors (Table 5). A prospective study is going on (Fleseriu et al. 2014).

Medical therapy should be selected according to drug properties and each patient's particular clinical situation (Table 2). A ketoconazole and octreotide effect was shown to be additive with improved clinical features and reduced cortisol production; however, a minimal proportion of cases exhibited normalized UFC (Vignati \& Loli 1996). In two studies, after 3-6 months of combined therapy, a complete response was shown in $67 \%$ and $90 \%$ of patients with a stepwise combination of pasireotide and cabergoline or pasireotide, cabergoline, and ketoconazole respectively (Feelders et al. 2010b,c, Vilar et al. 2010). In contrast to previously reported cases during long-term cabergoline monotherapy, patients on combined pasireotide-cabergoline treatment did not exhibit escapism (Feelders \& Hofland 2013). It would seem that UFC normalization in combination therapies remains at approximately $80 \%$ regardless of which drug is administered first: cabergoline with ketoconazole or, ketoconazole with cabergoline (Barbot et al. 2014).

A triple-drug combination has been recently evaluated as an alternative to urgent adrenalectomy (Kamenicky et al. 2011). A group of 11 patients with severe CD were simultaneously treated with mitotane (3-5 g/day), metyrapone (3-4.5 g/day), and ketoconazole (400-1200 mg/day, Table 5). Within days, UFC decreased significantly and clinical improvement permitted pituitary surgery in five patients. Although side effects were present, they were tolerable (Kamenicky et al. 2011). Ketoconazole with metyrapone might cause mineralocorticoid hypertension. Blood pressure should be monitored if this therapeutic approach is applied.
Pasireotide with temozolomide administered over 12 months revealed sustained control of tumor growth and ACTH secretion in a pituitary carcinoma, indicating that such a combination may be a promising option for aggressive pituitary tumors (Bode et al. 2010).

The degree of hypercortisolism at baseline could predict the doses needed to control cortisol excess (Vilar et al. 2010, Feelders \& Hofland 2013). Combination treatments that have been evaluated for CD treatment are summarized in Table 5 .

\section{Novel targets for treatment of CD}

\section{Epidermal growth factor receptor inhibitors}

Epidermal growth factor receptor (EGFR) has been studied as a therapeutic target for ACTH-secreting pituitary adenomas (Fukuoka et al. 2011). Normal pituitary and corticotrope adenomas express EGFR, which controls POMC expression. After blocking of EGFR with gefitinib, a tyrosine kinase inhibitor, POMC expression was attenuated, with inhibition of corticotrope cell proliferation and induced apoptosis (Fig. 3). The results were confirmed using canine and human corticotrope tumors as well as an athymic nude mouse model, indicating that inhibiting EGFR signaling with gefitinib may be a novel strategy for treating CD (Fukuoka et al. 2011). However, confirmation of efficacy in patients with $\mathrm{CD}$ requires clinical trials.

\section{Cell cycle regulators}

Animal and cell models have provided insights into mechanisms underlying the pathogenesis of ACTHsecreting pituitary adenomas, mostly due to cell cycle disruption. A classic example indicating the association of cell cycle regulators and pituitary tumorigenesis is derived from the heterozygous $\mathrm{Rb}$ mouse (Melmed 2003). The $R b$ $(R b 1)$ gene encodes a tumor suppressor that controls the G1/S cell cycle checkpoint. Rb phosphorylation by cyclindependent kinases (CDKs) releases the E2F transcription factor enabling S-phase progression (Fig. 3) (Liu et al. $2011 a, b$ ). Inhibitors of CDK4 (INK4) type (p16, p15, p18, and p19) and CIP/KIP type (p21, p27, and p57) suppress the action of CDK. Sequential activation and inactivation of protein kinase complexes regulate cell cycle progression (Melmed 2003). Heterozygous $R b^{+/-}$mice developed intermediate lobe POMC cell tumors at 12 months with $100 \%$ penetrance. Deletion of $p 27^{K i p 1}(C d k n 1 b)$ or $p 21$ (Cdkn1a) enhances intermediate lobe tumorigenesis in $\mathrm{Rb}^{+/-}$mice (Park et al. 1999). These results motivate the

Published by Bioscientifica Ltd. 
pharmacological assessment of a CDK2/cyclin E inhibitor, R-roscovitine (seliciclib; CYC202) in corticotrope pituitary adenomas. In transgenic POMC-pituitary tumortransforming gene (PTTG (PTTG1)) zebrafish embryos and in a mouse model of ACTH-secreting pituitary adenomas, R-roscovitine suppressed ACTH expression/ production and inhibited tumor growth (Liu et al. 2011b). Molecular analyses in vitro and in vivo showed upregulation of p27, p21, and p57 (CDKN1C), and downregulation of cyclin E expression (Fig. 3). The results indicate that use of selective CDK inhibitors may effectively target corticotrope tumor growth and hormonal secretion (Liu et al. 2011b).

\section{Therapeutic role of microRNA's}

MicroRNAs (or miRNAs) are noncoding, single-stranded RNAs constituting a novel class of gene regulators. miRNAs control diverse biological processes including cell growth, differentiation, and apoptosis by post-transcriptional regulation of target gene expression (He \& Hannon 2004). miRNA mutations or misexpression correlate with several human cancers indicating that miRNAs can function as tumor suppressors. Real-time PCR in corticotrope adenomas compared with normal pituitary tissue revealed downregulation of several miRNAs, including miR-15a (MIR15A), miR-16, and Let-7a among others (Amaral et al. 2009). Interestingly, $m i R-15 a$ and $m i R-16$ genes are colocalized with the $\mathrm{Rb}$ tumor suppressor on chromosome 13q14, which is commonly deleted in corticotropinomas. Let-7 miRNA negatively regulates high-mobility group A2 protein, which is highly expressed in pituitary adenomas, increasing aggressiveness of corticotrope adenomas and, therefore, contributing to pituitary tumorigenesis and progression (Qian et al. 2009). Genetic manipulation of miRNAs may induce tumor regression and decrease the activity of corticotrope adenomas.

\section{Potential future therapeutic targets}

Several transgenic mouse models have contributed important knowledge to understanding of human pituitary disease. Transgenic mice with metallothionein (mMT)-promoter-driven overexpression of CRH exhibited disruption of the HPA axis with elevated plasma ACTH and glucocorticoid levels, and development of CS (StenzelPoore et al. 1992).

Desmopressin (1-desamino-8-D-arginine vasopressin, DDVAP), a long-acting synthetic AVP analog, stimulates ACTH secretion from human pituitary corticotrope adenomas through V3 pituitary receptor stimulation.
The V3 pituitary receptor is located mainly in the anterior pituitary gland (Fig. 3) and has been previously classified as the V1b AVP receptor. Transgenic mice expressing the human AVP V3 receptor under the control of rat Pomc promoter sequences showed increased basal concentrations of corticosterone; however, no corticotrope tumors developed (Rene et al. 2002). AVP antagonists (vaptans) showed mainly antidiuretic effects, as they are selective V2 renal receptor antagonists. However, development of V3-receptor-specific antagonists could lead to a new class of agents that suppress ACTH secretion in corticotrope adenomas (Fig. 3; Ferone et al. 2013).

Manipulation of leukemia inhibitory factor (LIF) and the ATPase subunit of the chromatin remodeling Swi/Snf complex Brg1 may be good therapeutic targets for controlling hypercortisolism. LIF is a pleiotropic cytokine that enhances POMC transcription, ACTH secretion, and corticotrope cell proliferation, and is an essential protein for POMC repression (Auernhammer \& Melmed 2000). Brg1 stabilizes the interaction between GR and Nur77 (NGFI-B), a nuclear orphan receptor that is also essential for POMC transrepression (Bilodeau et al. 2006).

Testicular orphan nuclear receptor 4 (TR4) has been recently identified as another potential target for $\mathrm{CD}$ treatment. TR4 (NR2C2) was overexpressed in human corticotrope tumors and in human and mouse corticotrope tumor cell lines (Du et al. 2013). Consistently, TR4 overexpression in human and murine tumor cells increased POMC transcription, АCTH secretion, cellular proliferation, and tumor invasiveness. TR4 activated POMC transcription through a MAPK-mediated pathway (Du et al. 2013).

Vascular endothelial growth factor receptor 2 (VEGFR2 (KDR)), PTTG, and fibroblast growth factor expressions are associated with extrasellar extension and greater pituitary adenoma proliferative potential. These data provide useful information for novel targeted treatments. For example, treatment of a corticotrope carcinoma with bevacizumab, a monoclonal antibody that blocks VEGFRs, stopped tumor progression and induced CD control (Ortiz et al. 2012).

The rapamycin (mTOR) pathway is upregulated in pituitary adenomas. Human ACTH-secreting pituitary adenomas, however, express MTOR and its active phosphorylated isoform at levels similar to those of normal pituitary tissue. In addition, AtT-20 mice corticotrope adenoma cells were shown to be resistant to rapamycin. Interestingly, such resistance can effectively be overcome using octreotide as a cotreatment. If $\mathrm{CD}$ is treated first with an SRL, and then with an mTOR inhibitor, control of

Published by Bioscientifica Ltd. 
hypercortisolism may be more easily achieved (Ferone et al. 2013).

\section{Summary}

$\mathrm{CD}$ is a severe pituitary endocrine disorder with related long-term complications and increased mortality if not appropriately treated. Transsphenoidal surgery is the firstline treatment of choice; however, surgery does not result in a long-term cure for many patients. Recently, approved medical therapies target the corticotrope adenoma itself (i.e. pasireotide) or block cortisol effects in the periphery (i.e. mifepristone), thus providing new approaches and treatment options. The most commonly utilized clinical inhibitors of steroid biosynthesis are ketoconazole, metyrapone, and mitotane. Mitotane's mechanism of action seems to be multifactorial. Other steroidogenesis inhibitors interfere with cytochrome-P450-catalysed reactions. This mechanism of action has little selectivity and extra-adrenal adverse effects are likely. Daily doses should be titrated to maintain urinary and serum cortisol in the normal range, avoiding excessive suppression of adrenal function. However, glucocorticoid replacement is sometimes recommended with a 'block and replace' approach. A relatively new adrenal steroidogenesis inhibitor, LCI699, seems to be efficient and well tolerated; clinical trials are ongoing. Finally, in recent years, new molecular targets have been identified on corticotrope adenomas including EGFR, cell cycle regulators, and miRNAs.

\section{Declaration of interest}

D C-R declares that there is no conflict of interest that could be perceived as prejudicing the impartiality of the review.

\section{Funding}

M F has received research grants to Oregon Health and Science University from Corcept Therapeutics, Ipsen, and Novartis and has been an ad hoc consultant/advisor for Genentech, Ipsen, Novartis, and Pfizer.

\section{Acknowledgements}

The authors thank Shirley McCartney, PhD, for editorial assistance.

\section{References}

Aghi MK 2008 Management of recurrent and refractory Cushing disease. Nature Clinical Practice. Endocrinology \& Metabolism 4 560-568. (doi:10.1038/ncpendmet0947)

Alberti KG, Christensen NJ, Christensen SE, Hansen AP, Iversen J, Lundbaek K, Seyer-Hansen K \& Orskov H 1973 Inhibition of insulin secretion by somatostatin. Lancet 2 1299-1301. (doi:10.1016/S01406736(73)92873-0)

Alexandraki KI, Kaltsas GA, Ie Roux CW, Fassnacht M, Ajodha S, ChristCrain M, Akker SA, Drake WM, Edwards R, Allolio B et al. 2010 Assessment of serum-free cortisol levels in patients with adrenocortical carcinoma treated with mitotane: a pilot study. Clinical Endocrinology 72 305-311. (doi:10.1111/j.1365-2265.2009.03631.x)

Allolio B, Schulte HM, Kaulen D, Reincke M, Jaursch-Hancke C \& Winkelmann W 1988 Nonhyponotic low-dose etomidate for rapid correction of hypercortisolemia in Cushing's syndrome. Klinische Wochenschrift 10 e37-e40. (doi:10.1007/BF01735795)

Amaral FC, Torres N, Saggioro F, Neder L, Machado HR, Silva WA Jr, Moreira AC \& Castro M 2009 MicroRNAs differentially expressed in ACTH-secreting pituitary tumors. Journal of Clinical Endocrinology and Metabolism 94 320-323. (doi:10.1210/jc.2008-1451)

Ambrosi B, Bochicchio D, Fadin C, Colombo P \& Faglia G 1990 Failure of somatostatin and octreotide to acutely affect the hypothalamicpituitary-adrenal function in patients with corticotropin hypersecretion. Journal of Endocrinological Investigation 13 257-261. (doi:10.1007/BF03349555)

Arnardottir S \& Sigurjonsdottir HA 2011 The incidence and prevalence of Cushing's disease may be higher than previously though: results from a retrospective study in Iceland 1955 through 2009. Clinical Endocrinology 74 792-793. (doi:10.1111/j.1365-2265.2010.03961.x)

Assie G, Bahurel H, Coste J, Silvera S, Kujas M, Dugué MA, Karray F, Dousset B, Bertherat J, Legmann P et al. 2007 Corticotroph tumor progression after adrenalectomy in Cushing's disease: a reappraisal of Nelson's syndrome. Journal of Clinical Endocrinology and Metabolism 92 172-179. (doi:10.1210/jc.2006-1328)

Auernhammer CJ \& Melmed S 2000 Leukemia-inhibitory factorneuroimmune modulator of endocrine function. Endocrine Reviews 21 313-345. (doi:10.1210/edrv.21.3.0400)

Bamberger CM, Schulte HM \& Chrousos GP 1996 Molecular determinants of glucocorticoid receptor function and tissue sensitivity to glucocorticoids. Endocrine Reviews 17 245-261. (doi:10.1210/edrv-17-3-245)

Barbot M, Albiger N, Ceccato F, Zilio M, Frigo MZ, Denaro L, Mantero F \& Scaroni C 2014 Combination therapy for Cushing's disease: effectiveness of two schedules of treatment. Should we start with cabergoline or ketoconazole? Pituitary 17 109-117. (doi:10.1007/s11102-013-0475-3)

Batista DL, Zhang X, Gejman R, Ansell PJ, Zhou Y, Johnson SA, Swearingen B, Hedley-Whyte ET, Stratakis CA \& Klibanski A 2006 The effects of SOM230 on cell proliferation and adrenocorticotropin secretion in human corticotroph pitutiary adenomas. Journal of Clinical Endocrinology and Metabolism 91 4482-4488. (doi:10.1210/jc.2006-1245)

Baudry C, Coste J, Bou Khalil R, Silvera S, Guignat L, Guibourdenche J, Abbas H, Legmann P, Bertagna X \& Bertherat J 2012 Efficiency and tolerance of mitotane in Cushing's disease in 76 patients from a single center. European Journal of Endocrinology 167 473-481. (doi:10.1530/ EJE-12-0358)

Ben-Shlomo A, Schimd H, Wawrowsky K, Pichurin O, Hubina E, Chesnokova V, Liu NA, Culler M \& Melmed S 2010 Differential ligandmediated pituitary somatostatin receptor subtype signaling: implications for corticotroph tumor therapy. Journal of Clinical Endocrinology and Metabolism 94 4342-4350. (doi:10.1210/jc.2009-1311)

Bertagna X 1994 Proopiomelanocortin-derived peptides. Endocrinology and Metabolism Clinics of North America 23 467-485.

Bertagna X, Bertagna C, Luton JP, Husson JM \& Girard F 1984 The new steroid analog RU-486 inhibits glucocorticoid action in man. Journal of Clinical Endocrinology and Metabolism 59 25-28. (doi:10.1210/jcem-59-1-25)

Bertagna X, Bertagna C, Laudat MH, Husson JM, Girard F \& Luton JP 1986 Pituitary-adrenal response to the antiglucocorticoid action of RU486 in Cushing's syndrome. Journal of Clinical Endocrinology and Metabolism 63 639-643. (doi:10.1210/jcem-63-3-639)

Bertagna X, Guignat L, Groussin L \& Bertherat J 2006 Cushing disease. Best Practice \& Research. Clinical Endocrinology \& Metabolism 23 607-623. (doi:10.1016/j.beem.2009.06.001) 
Bertagna X, Pivonello R, Fleseriu M, Zhang Y, Robinson P, Taylor A, Watson CE, Maldonado M, Hamrahian AH, Boscaro M et al. 2014 LCI699, a potent $11 \beta$-hydroxylase inhibitor, normalizes urinary cortisol in patients with Cushing's disease: results from a multicenter, proof-of-concept study. Journal of Clinical Endocrinology and Metabolism 99 1375-1383. (doi:10.1210/jc.2013-2117)

Berwaerts JJ, Verhelst JA, Verhaert GC, Verhaegen AA \& Abs RE 1998 Corticotropin-dependent Cushing's syndrome in older people: presentation of five cases and therapeutical use of ketoconazole. Journal of the American Geriatrics Society 46 880-884.

Biller BM, Grossman AB, Stewart PM, Melmed S, Bertagna X, Bertherat J, Buchfelder M, Colao A, Hermus AR, Hofland LJ et al. 2008 Treatment of adrenocorticotropin-dependent Cushing's syndrome: a consensus statement. Journal of Clinical Endocrinology and Metabolism 93 2454-2462. (doi:10.1210/jc.2007-2734)

Biller BM, Colao A, Petersenn S, Bonert V \& Boscaro M 2010 Review: Prolactinomas, Cushing's disease and acromegaly: debating the role of medical therapy for secretory pituitary adenomas. BMC Endocrine Disorders 10 1-14. (doi:10.1186/1472-6823-10-10)

Bilodeau S, Vallette-Kasic S, Gauthier Y, Figarella-Branger D, Brue T, Berthelet F, Lacroix A, Batista D, Stratakis C, Hanson J et al. 2006 Role of Brg1 and HDAC2 in GR trans-repression of the pituitary POMC gene and misexpression in Cushing disease. Genes and Development 20 2871-2886. (doi:10.1101/gad.1444606)

Bledsoe T, Island DP, Ney RL \& Liddle GW 1964 An effect of o,p'-DDD on the extra-adrenal metabolism of cortisol in man. Journal of Clinical Endocrinology and Metabolism 24 1303-1311. (doi:10.1210/ jcem-24-12-1303)

Bode H, Seiz M, Lammert A, Brockmann MA, Back W, Hammes HP \& Thomé C 2010 SOM230 (pasireotide) and temozolomide achieve sustained control of tumour progression and ACTH secretion in pituitary carcinoma with widespread metastases. Experimental and Clinical Endocrinology \& Diabetes 118 760-763. (doi:10.1055/s-00301253419)

Boden G, Ryan IG, Eisenschmid BL, Shelmet JJ \& Owen OE 1986 Treatment of inoperable glucagonoma with the long-acting somatostatin analogue SMS 201-995. New England Journal of Medicine 314 1686-1689. (doi:10.1056/NEJM198606263142606)

Bolland MJ, Holdaway IM, Berkeley JE, Lim S, Dransfield WJ, Conaglen JV, Croxson MS, Gamble GD, Hunt PJ \& Toomath RJ 2011 Mortality and morbidity in Cushing's syndrome in New Zeland. Clinical Endocrinology 75 436-442. (doi:10.1111/j.1365-2265.2011.04124.x)

Boscaro M, Barzon L, Fallo F \& Sonino N 2001 Cushing's syndrome. Lancet 357 783-791. (doi:10.1016/S0140-6736(00)04172-6)

Boscaro M, Ludiam WH, Atkinson B, Glusman JE, Petersenn S, Reincke M, Snyder P, Tabarin A, Biller BM, Findling J et al. 2009 Treatment of pituitary-dependent Cushing's disease with the multireceptor ligand somatostatin analog pasireotide (SOM230): a multicenter, phase II trial. Journal of Clinical Endocrinology and Metabolism 94 115-122. (doi:10.1210/jc.2008-1008)

Brazeau P, Vale W, Burgus R, Ling N, Nutcher M, Rivier J \& Guillemin R 1973 Hypothalamic polypeptide that inhibits the secretion of immunoreactive pituitary growth hormone. Science 179 77-79. (doi:10.1126/science.179.4068.77)

de Bruin C, Feelders RA, Lamberts SW \& Hofland LJ 2009 Somatostatin and dopamine receptors as targets for medical treatment of Cushing's syndrome. Reviews in Endocrine \& Metabolic Disorders 10 91-102. (doi:10.1007/s11154-008-9082-4)

de Bruin C, Hofland LJ, Nieman LK, van Koetsveld PM, Waaijers AM, Sprij-Mooij DM, van Essen M, Lamberts SW, de Herder WW \& Feelders RA 2012 Mifepristone effects on tumor somatostatin receptor expression in two patients with Cushing's syndrome due to ectopic adrenocorticotropin secretion. Journal of Clinical Endocrinology and Metabolism 97 455-462. (doi:10.1210/jc.2011-1264)

Budry L, Balsalobre A, Gauthier Y, Khetchoumian K, L'Honore A, Vallette S, Brue T, Figarella-Branger D, Meij B \& Drouin J 2012 The selector gene
Pax7 dictates alternate pituitary cell fates through its pioneer action on chromatin remodeling. Genes and Development 26 2299-2310. (doi:10.1101/gad.200436.112)

Calhoun DA, White WB, Krum H, Guo W, Bermann G, Trapani A, Leftkowitz MP \& Ménard J 2011 Effects of a novel aldosterone synthase inhibitor for treatment of primary hypertension: results of a randomized, double-blind, placebo- and active-controlled phase 2 trial. Circulation 124 1945-1955. (doi:10.1161/CIRCULATIONAHA.111. 029892)

Camacho AM, Cash R, Brough AJ \& Wilroy RS 1967 Inhibition of adrenal steroidogenesis by amino-glutethimide and the mechanism of action. Journal of the American Medical Association 202 20-26. (doi:10.1001/ jama.1967.03130140078010)

Castinetti F, Morange I, Jaquet P, Conte-Devoix B \& Brue T 2008 Ketoconazole revisited: a preoperative or postoperartive treatment in Cushing disease. European Journal of Endocrinology 158 91-99. (doi:10.1530/EJE-07-0514)

Castinetti F, Fassnacht M, Johanssen S, Terzolo M, Bouchard P, Chanson P, Do Cao C, Morange I, Picó A, Ouzounian S et al. 2009 Merits and pitfalls of mifepristone in Cushing's syndrome. European Journal of Endocrinology 160 1003-1010. (doi:10.1530/EJE-09-0098)

Castinetti F, Laurence G, Pauline G, Marie M, Peter K, Delphine D, Philippe C, Fiorina L, Bruno D, Vantyghem MC et al. 2014 Ketoconzaole in Cushing's disease: is it worth a try? Journal of Clinical Endocrinology and Metabolism 99 1623-1630. (doi:10.1210/jc.2013-3628)

Cavagnini F, Paneral AE, Valentini F, Bulgheroni P, Peracchi M \& Pinto M 1975 Inhibition of ACTH response to oral and intravenous metyrapone by antiserotonergic treatment in man. Journal of Clinical Endocrinology and Metabolism 41 143-148. (doi:10.1210/jcem-41-1-143)

Cavagnini F, Invitti C \& Polli EE 1984 Sodium valproate in Cushing disease (letter). Lancet 2 162. (doi:10.1016/S0140-6736(84)91074-2)

Chow JT, Thompson GB, Grant CS, Farley DR, Richards ML \& Young WF Jr 2008 Bilateral laparoscopic adrenalectomy for corticotrophindependent Cushing's syndrome: a review of the Mayo Clinic experience. Clinical Endocrinology 68 513-519. (doi:10.1111/j.13652265.2007.03082.x)

Chu JW, Matthias DF, Belanoff J, Schatzberg A, Hoffman AR \& Feldman D 2001 Succesful long-term treatment of refractory Cushing's disease with high-dose mifepristone (RU486). Journal of Clinical Endocrinology and Metabolism 86 3568-3573. (doi:10.1210/jcem.86.8.7740)

Colao A, Pivonello R, Tripodi FS, Orio F Jr, Ferone D, Cerbone G, Di Somma C, Merola B \& Lombardi G 1997 Failure of long-term therapy with sodium valproate in Cushing's disease. Journal of Endocrinological Investigation 20 387-392. (doi:10.1007/BF03347989)

Colao A, Petersenn S, Newell-Price J, Findling JW, Gu F, Maldonado M, Schoenherr U, Mills D, Salgado LR \& Biller BM 2012 A 12-month phase 3 study of pasireotide in Cushing's disease. New England Journal of Medicine 366 914-924. (doi:10.1056/NEJMoa1105743)

Colao A, De Block C, Gaztambide MS, Kumar S, Seufert J \& Casanueva FF 2014 Managing hyperglycemia in patients with Cushing's disease treated with pasireotide: medical expert recommendations. Pituitary $\mathbf{1 7}$ 180-186. (doi:10.1007/s11102-013-0483-3)

Cueto C \& Brown JHU 1958 Biological studies on an adrenocorticolytic agent and the isolation of the active components. Endocrinology 62 326-333. (doi:10.1210/endo-62-3-326)

Cuevas-Ramos D \& Fleseriu M 2014 Somatostatin receptor ligands and resistance to treatment in pituitary adenomas. Journal of Molecular Endocrinology 52 R223-R240. (doi:10.1530/JME-14-0011)

Dekkers OM, Biermasz NR, Pereira AM, Roelfsema F, van Aken MO, Voormolen JH \& Romijn JA 2007 Mortality in patients treated for Cushing's disease is increased, compared with patients treated for nonfunctioning pituitary macroadenoma. Journal of Clinical Endocrinology and Metabolism 92 976-981. (doi:10.1210/jc.2006-2112)

Delgado V, Biermasz NR, van Thiel SW, Ewe SH, Marsan NA, Holman ER, Feelders RA, Smit JW, Bax JJ \& Pereira AM 2012 Changes in heart valve structure and function in patients treated with dopamine agonists 
for prolactinomas, a 2-year follow-up study. Clinical Endocrinology $\mathbf{7 7}$ 99-105. (doi:10.1111/j.1365-2265.2011.04326.x)

Dewis DC, Bu'lock DE, Earnshaw R \& Kelly WF 1983 Experience with trilostane in the treatment of Cushing's syndrome. Clinical Endocrinology 18 533-540. (doi:10.1111/j.1365-2265.1983.tb00590.x)

Dickstein G, Spindel A, Schechner C, Adawi F \& Gutman H 1991 Spontaneous remission in Cushing's disease. Archives of Internal Medicine 151 185-189. (doi:10.1001/archinte.1991.00400010171028)

Dillard TH, Gultekin SH, Delashaw JB Jr, Yedinak CG, Neuwelt EA \& Fleseriu M 2011 Temozolomide for corticotroph pituitary adenomas refractory to standard therapy. Pituitary 14 80-91. (doi:10.1007/s11102010-0264-1)

Du L, Bergsneider M, Mirsadrael L, Young SH, Jonker JW, Downes M, Yong WH, Evans RM \& Heaney AP 2013 Evidence for orphan nuclear receptor TR4 in the etiology of Cushing disease. PNAS 110 8555-8560. (doi:10.1073/pnas.1306182110)

Engelhardt D \& Weber MM 1994 Therapy of Cushing's syndrome with steroid biosynthesis inhibitors. Journal of Steroid Biochemistry and Molecular Biology 49 261-267. (doi:10.1016/0960-0760(94)90267-4)

Engelhardt D, Mann K, Hormann R, Braun S \& Karl H 1983 Ketoconazole inhibits cortisol secretion of an adrenal adenoma in vivo and in vitro. Klinische Wochenschrift 61 373-375. (doi:10.1007/BF01485030)

Estrada J, Boronat M, Mielgo M, Magallón R, Millan I, Diez S, Lucas T \& Barceló B 1997 The long-term outcome of pituitary irradiation after unsuccessful transsphenoidal surgery in Cushing's disease. New England Journal of Medicine 336 172-177. (doi:10.1056/ NEJM199701163360303)

Feelders RA \& Hofland LJ 2013 Medical treatment of Cushing's disease. Journal of Clinical Endocrinology and Metabolism 98 425-438. (doi:10.1210/jc.2012-3126)

Feelders RA, de Bruin C \& Pereira AM 2010a Medical treatment of Cushing's disease with pasireotide mono or combination therapy with cabergoline and ketoconazole modulates somatostatin receptor subtype expression on corticotroph tumor cells [abstract OR14-6]. Endocrine Reviews 31(suppl 1) S845.

Feelders RA, Hofland LJ \& de Herder WW $2010 \mathrm{~b}$ Medical treatment of Cushing syndrome: adrenal-blocking drugs and ketoconazole. Neuroendocrinology 92(Suppl 1) 111-115. (doi:10.1159/000314292)

Feelders RA, de Bruin C, Pereira AM, Romjin JA, Netea-Maier RT, Hermus AR, Zelissen PM, van Heerebeek R, de Jong FH, van der Lely AJ et al. 2010c Pasireotide alone or with cabergoline and ketoconazole in Cushing's disease. New England Journal of Medicine 362 1846-1848. (doi:10.1056/NEJMc1000094)

Feelders RA, Pulgar SJ, Kempel A \& Pereira AM 2012 The burden of Cushing's disease (CD): clinical and health-related quality of life aspects. European Journal of Endocrinology 167 11-26. (doi:10.1530/EJE-11-1095)

Feldman D 1986 Ketoconazole and other imidazole derivatives as inhibitors of steroidogenesis. Endocrine Reviews 7 409-420. (doi:10.1210/edrv-7-4-409)

Fernando MA \& Heaney AP $2005 \alpha 1$-Adrenergic receptor antagonists: novel therapy for pituitary adenomas. Molecular Endocrinology 19 3085-3096. (doi:10.1210/me.2004-0471)

Ferone D, Pivonello C, Vitale G, Zatelli MC, Colao A \& Pivonello R 2013 Molecular basis of pharmacological therapy in Cushing's disease. Endocrine 46 181-198. (doi:10.1007/s12020-013-0098-5)

Ferrari C, Bertazzoni A \& Ghezzi M 1977 More on cyproheptadine (letter). New England Journal of Medicine 296 576-577. (doi:10.1056/ NEJM197703102961022)

Fleseriu M 2012 Medical management of persistent and recurrent Cushing disease. Neurosurgery Clinics of North America 23 653-668. (doi:10.1016/ j.nec.2012.06.012)

Fleseriu M \& Petersenn S 2012 Medical management of Cushing's disease: what is the future? Pituitary 15 330-341. (doi:10.1007/s11102-012-0397-5)

Fleseriu M \& Petersenn S 2013 New avenues in the medical treatment of Cushing's disease: corticotroph tumor targeted therapy. Journal of Neuro-Oncology 114 1-11. (doi:10.1007/s11060-013-1151-1)
Fleseriu M, Loriaux DL \& Ludlam WH 2007 Second-line treatment for Cushing's disease when initial pituitary surgery is unsuccessful. Current Opinion in Endocrinology, Diabetes, and Obesity 14 323-328. (doi:10.1097/MED.0b013e328248b498)

Fleseriu M, Biller BM, Findling JW, Molitch ME, Schteingart DE, Gross C \& SEISMIC Study investigators 2012 Mifepristone, a glucocorticoid receptor antagonist, produces clinical and metabolic benefits in patients with Cushing's syndrome. Journal of Clinical Endocrinology and Metabolism 97 2039-2049. (doi:10.1210/jc.2011-3350)

Fleseriu M, Pivonello R, Pedroncelli AM, Patino H, Ye M, Aout M \& Feelders RA 2014 Study design of a phase II trial of subcutaneous pasireotide alone or combined with cabergoline in patients with Cushing's disease. Presented at The 96th Endocrine Society's Annual Meeting/16th International Congress of Endocrinology, Chicago, IL, USA. June 21-24, 2014. Poster Board MON-0715.

Fukuoka H, Cooper O, Ben-Shlomo A, Mamelak A, Ren SG, Bruyette D \& Melmed S 2011 EGFR as therapeutic target for human, canine, and mouse ACTH-secreting pitutiary adenomas. Journal of Clinical Investigation 121 4712-4721. (doi:10.1172/JCI60417)

Gatto F \& Hofland LJ 2011 The role of somatostatin and dopamine D2 receptors in endocrine tumors. Endocrine-Related Cancer 18 R233-R251. (doi:10.1530/ERC-10-0334)

Godbout A, Manavela M, Danilowicz K, Beauregard H, Bruno OD \& Lacroix A 2010 Cabergoline monotherapy in the long-term treatment of Cushing's disease. European Journal of Endocrinology 163 709-716. (doi:10.1530/EJE-10-0382)

Gower DB 1974 Modifiers of steroid-hormone metabolism: a review of their chemistry, biochemistry and clinical applications. Journal of Steroid Biochemistry 5 501-523. (doi:10.1016/0022-4731(74)90051-X)

Greenman Y 2010 Management of dyslipidemia in Cushing syndrome. Neuroendocrinology 92(Suppl 1) 91-95. (doi:10.1159/000314294)

He L \& Hannon GJ 2004 MicroRNAs: small RNAs with a big role in gene regulation. Nature Reviews. Genetics 5 522-531. (doi:10.1038/nrg1379)

Heaney AP 2004 PPAR- $\gamma$ in Cushing's disease. Pituitary 7 265-269. (doi:10.1007/s11102-005-1430-8)

Heaney AP, Fernando M, Yong WH \& Melmed S 2002 Functional PPAR- $\gamma$ receptor is a novel therapeutic target for ACTH-secreting pitutiary adenomas. Nature Medicine 8 1281-1287. (doi:10.1038/nm784)

Henry R, Mudaliar S, Hermosillo Reséndiz K, Ligueros-Saylan M, Chenji S \& Golor G 2011 Mechanism and management of hyperglycemia associated with pasireotide: results from studies in healthy volunteers. Endocrine Reviews 32 P3-P274. (doi:10.1210/er.2009-0043)

Hertz R, Pittman JA \& Graff MM 1956 Amphenone: toxicity and effects on adrenal and thyroid function in man. Journal of Clinical Endocrinology and Metabolism 16 705-723. (doi:10.1210/jcem-16-6-705)

Heyn J, Greiger C \& Hinske CL 2012 Medical suppression of hypercortisolemia in Cushing's syndrome with particular consideration of etomidate. Pituitary 15 117-125. (doi:10.1007/s11102-011-0314-3)

van der Hoek J, Waaijers M, van Koetsveld PM, Sprij-Mooij D, Feelders RA, Schmid HA, Schoeffter P, Hoyer D, Cervia D, Taylor JE et al. 2005 Distinct functional properties of native somatostatin receptor subtype 5 compared with subtype 2 in the regulation of ACTH release by corticotroph tumor cells. American Journal of Physiology. Endocrinology and Metabolism 289 E278-E287. (doi:10.1152/ajpendo. 00004.2005)

Hofland LJ, van der Hoek J, Feelders R, van Aken MO, van Koetsveld PM, Waaijers M, Sprij-Mooij D, Bruns C, Weckbecker G, de Herder WW et al. 2005 The multi-ligand somatostatin analogue SOM230 inhibits ACTH secretion by cultured human corticotroph adenomas via somatostatin receptor type 5. European Journal of Endocrinology 152 645-654. (doi:10.1530/eje.1.01876)

Iino K, Oki Y, Yamashita M, Matsushita F, Hayashi C, Yogo K, Nishizawa S, Yamada S, Maekawa M, Sasano H et al. 2010 Possible relevance between prohormone convertase 2 expression and tumor growth in human adrenocorticotropin-producing pituitary adenoma. Journal of Clinical Endocrinology and Metabolism 95 4003-4011. (doi:10.1210/jc.2009-2716) http://joe.endocrinology-journals.org DOI: $10.1530 / J O E-14-0300$
() 2014 Society for Endocrinology Printed in Great Britain 
Jeffcoate WJ, Rees LH, Tomlin S, Jones AE, Edwards CR \& Besser GM 1977 Metyrapone in long-term management of Cushing's disease. British Medical Journal 23 215-217.

Jimenez-Rema L, Leal-Cerro A, García J, García-Luna PP, Astorga R \& Bernal G 1989 In vitro effects of ketoconazole on corticotrope cell morphology and ACTH secretion of two pituitary adenomas recovered from patients with Nelson's syndrome. Acta Endocrinologica 121 185-190. (doi:10.1530/acta.0.1210185)

Johanssen S \& Allolio B 2007 Mifepristone (RU486) in Cushing's syndrome. European Journal of Endocrinology 157 561-569. (doi:10.1530/EJE07-0458)

Kamenicky P, Droumaguet C, Salenave S, Blanchard A, Jublanc C, Gautier JF, Brailly-Tabard S, Leboulleux S, Schlumberger M, Baudin E et al. 2011 Mitotane, metyrapone, and ketoconazol combination therapy as an alternative to rescue adrenalectomy for severe ACTH-dependent Cushing's syndrome. Journal of Clinical Endocrinology and Metabolism 96 2796-2804. (doi:10.1210/jc.2011-0536)

Karaca Z, Tanriverdi F \& Unluhizarci K 2010 Pregnancy and pituitary disorders. European Journal of Endocrinology 162 453-475. (doi:10.1530/ EJE-09-0923)

Koerker DJ, Ruch W, Chideckel E, Palmer J, Goodner CJ, Ensinck J \& Gale CC 1974 Somatostatin: hypothalamic inhibitor of the endocrine pancreas. Science 184 482-484. (doi:10.1126/science.184.4135.482)

Koppeschaar HP, Croughs RJ, Thijseeen JH \& Schwarz F 1986 Response to neurotransmitter modulating drugs in patients with Cushing disease. Clinical Endocrinology 25 661-667. (doi:10.1111/j.1365-2265.1986. tb03621.x)

Kreutzer J, Jeske I, Hofmann B, Blumcke I, Fahlbusch R, Buchfelder M \& Buslei R 2009 No effect of the PPAR- $\gamma$ agonist rosiglitazone on ACTH or cortisol secretion in Nelson's syndrome and Cushing's disease in vitro and in vivo. Clinical Neuropathology 28 430-439.

Krieger DT, Amorosa L \& Linick F 1975 Cyproheptadine-induced remission of Cushing's disease. New England Journal of Medicine 293 893-896. (doi:10.1056/NEJM197510302931802)

Kroiss M, Quinkler M, Lutz WK, Allolio B \& Fassnacht M 2011 Drug interactions with mitotane by induction of CYP3A4 metabolism in the clinical management of adrenocortical carcinoma. Clinical Endocrinology 75 585-591. (doi:10.1111/j.1365-2265.2011.04214.x)

Labeur M, Paez-Pereda M \& Arzt E 2009 Potential of retinoic acid derivatives for the treatment of corticotroph pitutiary adenomas. Reviews in Endocrine \& Metabolic Disorders 10 103-109. (doi:10.1007/ s11154-008-9080-6)

Lamberts SW \& Birkehager JC 1976 Bromocriptine in Nelson's syndrome and Cushing's disease. Lancet 2 811. (doi:10.1016/S0140-6736(76) 90656-5)

Lamberts SW, Stefanko SZ, de Lange SA, Fermin H, van der Vijver JC, Weber RF \& de Jong FH 1980 Failure of clinical remission after transsphenoidal removal of a microadenoma in a patient with Cushing disease: multiple hyperplastic and adenomatous cell nets in surrounding pitutiary tissue. Journal of Clinical Endocrinology and Metabolism 50 793-795. (doi:10.1210/jcem-50-4-793)

Lamberts SW, de Lange SA \& Stefanko SZ 1982 Adrenocorticotropinsecreting pitutiary adenomas originate from the anterior or the intermediate lobe in Cushing's disease: diferentes in the regulation of hormone secretion. Journal of Clinical Endocrinology and Metabolism 54 286-291. (doi:10.1210/jcem-54-2-286)

Lamberts SW, Uitterlinden P \& Klijn JM 1989a The effect of the long-acting somatostatin analogue SMS 201-995 on ACTH secretion in Nelson's syndrome and Cushing's disease. Acta Endocrinologica 120 760-766. (doi:10.1530/acta.0.1200760)

Lamberts SW, Zuyderwijk J, den Holder F, van Koetsveld P \& Hofland L $1989 b$ Studies on the conditions determing the inhibitory effect of somatostatin on adrenocorticotropin, prolactin and thyrotropin release by cultured rat pituitary cells. Neuroendocrinology $\mathbf{5 0} 44-50$. (doi:10.1159/000125200)
Leiba S, Weinstein R, Shindel B, Lapidot M, Stern E, Levavi H, Rusecki Y \& Abramovici A 1989 The protracted effect of o,p'-DDD in Cushing's disease and its impact on adrenal morphogenesis of young human embryo. Annales d'Endocrinologie 50 49-53.

Liddle GW, Estep HL, Kendall JW, Williams WC Jr \& Townes AW 1959 Clinical application of a new test of pituitary reserve. Journal of Clinical Endocrinology and Metabolism 19 875-894. (doi:10.1210/jcem-19-8-875)

Lila AR, Gopal RA, Acharya SV, George J, Sarathi V, Bandgar T, Menon PS \& Shah NS 2010 Efficacy of cabergoline in uncured (persistent or recurrent) Cushing disease after pituitary surgical treatment with or without radiotherapy. Endocrine Practice 16 968-976. (doi:10.4158/ EP10031.OR)

Lindsay JR, Jonklaas J, Oldfield EH \& Nieman LK 2005 Cushing's syndrome during pregnancy: personal experience and review of the literature. Journal of Clinical Endocrinology and Metabolism 90 3077-3083. (doi:10.1210/jc.2004-2361)

Liu NA, Ben-Shlomo A \& Melmed S 2011a Molecular biology of Cushing's disease. In Cushing's Disease, Endocrine Updates, vol 31, ch 2, pp. 19-32. Eds B Swearingen and BMK Biller. New York, NY, USA: Springer Science. (doi:10.1007/978-1-4614-0011-0_2)

Liu NA, Jiang H, Ben-Shlomo A, Wawrowsky K, Fan XM, Lin S \& Melmed S $2011 b$ Targeting zebrafish and murin pituitary corticotroph tumors with a cyclin-dependent kinase (CDK) inhibitor. PNAS 108 8414-8419. (doi:10.1073/pnas.1018091108)

Loli P, Berselli ME \& Tagliaferri M 1986 Use of ketoconazole in the treatment of Cushing's syndrome. Journal of Clinical Endocrinology and Metabolism 63 1365-1371. (doi:10.1210/jcem-63-6-1365)

Loose DS, Stover EP \& Feldman D 1983 Ketoconazole binds to glucocorticoid receptors and exhibits glucocorticoid antagonism activity in cultured cells. Journal of Clinical Investigation 72 404-408. (doi:10.1172/JCI110982)

Luton JP, Mahoudeau JA, Bouchard P, Thieblot P, Hautecouverture M, Simon D, Laudat MH, Tourtou Y \& Bricaire H 1979 Treatment of Cushing's disease by o,p'DDD. Survey of 62 cases. New England Journal of Medicine 300 459-464. (doi:10.1056/NEJM197903 013000903)

Mannelli M, Cantini G, Poli G, Mangoni M, Nesi G, Canu L, Rapizzi E, Borgogni E, Ercolino T, Piccini V et al. 2010 Role of the PPAR- $\gamma$ system in normal and tumoral pituitary corticotropic cells and adrenal cells. Neuroendocrinology 92 23-27. (doi:10.1159/000314312)

Maraka GB \& Stark E 1974 Effect of gamma amino-butyric acid (GABA) and GABA antagonist drugs on ACTH release. Neuroendocrinology 16 178-190. (doi:10.1159/000122564)

Melmed S 2003 Mechanisms for pituitary tumorigenesis: the plastic pitutiary. Journal of Clinical Investigation 112 1603-1618. (doi:10.1172/ JCI20401)

Miller JW \& Crapo L 1993 The medical treatment of Cushing's syndrome. Endocrine Reviews 14 443-458. (doi:10.1210/edrv-14-4-443)

Miller GM, Alexander JM, Bikkal HA, Katznelson L, Zervas NT \& Klibanski A 1995 Somatostatin receptor subtype gene expression in pituitary adenomas. Journal of Clinical Endocrinology and Metabolism $\mathbf{8 0}$ 1386-1392. (doi:10.1210/jcem.80.4.7714115)

Misbin RI, Canary J \& Williard D 1976 Aminoglutethimide in the treatment of Cushing's syndrome. Journal of Clinical Pharmacology 16 645-651. (doi:10.1002/j.1552-4604.1976.tb01504.x)

Missale C, Nash SR, Robinson SW, Jaber M \& Caron MG 1998 Dopamine receptors: from structure to function. Physiological Reviews 78 189-225.

Morcos M, Fohr B, Tafel J, Pfisterer F, Hamann A, Humpert P, Bode H, Schwenger V, Zeier M, Becker C et al. 2007 Long-term treatment of central Cuhsing's syndrome with rosiglitazone. Experimental and Clinical Endocrinology \& Diabetes 115 292-297. (doi:10.1055/s-2007-970162)

Murray RD, Kim K, Ren SG, Lewis I, Weckbecker G, Bruns C \& Melmed S 2004 The novel somatostatin ligand (SOM230) regulates human and rat anterior pituitary hormone secretion. Journal of Clinical Endocrinology and Metabolism 89 3027-3032. (doi:10.1210/jc.2003-031319) 
Nader N, Raverot G, Emptoz-Bonneton A, Déchaud H, Bonnay M, Baudin E \& Pugeat M 2006 Mitotante has an estrogenic effect on sex hormonebinding globulin and corticosteroid-binding globulin in humans. Journal of Clinical Endocrinology and Metabolism 91 2165-2170. (doi:10.1210/jc.2005-2157)

Nelson AA \& Woodard G 1949 Severe adrenal cortical atrophy (cytotoxic) and hepatic damage produced in dogs by feeding 2,2-bis(parachrorophenyl)-1,1-dichlorethane (DDD or TDE). Archives of Pathology 48 387-394.

Newell-Price J, Bertagna X, Grossman AB \& Nieman LK 2006 Cushing's syndrome. Lancet 367 1605-1617. (doi:10.1016/S0140-6736(06)68699-6)

Nieman LK 2002 Medical therapy for Cushing's disease. Pituitary 5 77-82. (doi:10.1023/A:1022308429992)

Nieman LK, Chrousos GP, Kellner C, Spitz IM, Nisula BC, Cutler GB, Merriam GR, Bardin CW \& Loriaux DL 1985 Succesful treatment of Cushing's syndrome with the glucocorticoid antagonist RU-486. Journal of Clinical Endocrinology and Metabolism 61 536-540. (doi:10.1210/jcem-61-3-536)

Nissen SE \& Wolski K 2010 Rosiglitazone revisited: an updated metaanalysis of risk for myocardial infarction and cardiovascular mortality. Archives of Internal Medicine 170 1191-1201. (doi:10.1001/archinternmed.2010.207)

Ortiz LD, Syro LV, Scheithauer BW, Ersen A, Uribe H, Fadul CE, Rotondo F, Horvath E \& Kovacs K 2012 Anti-VEGF therapy in pitutiary carcinoma. Pituitary 15 445-449. (doi:10.1007/s11102-011-0346-8)

Park MS, Rosai J, Nguyen HT, Capodieci P, Cordon-Cardo C \& Koff A 1999 p27 and $\mathrm{Rb}$ are on overlapping pathways suppressing tumorigenesis in mice. PNAS 96 6382-6387. (doi:10.1073/pnas.96.11.6382)

van der Pas R, Hofland L, Hofland J, Taylor AE, Arit W, Steenbergen J, van Koetsveld PM, de Herder WW, de Jong FH \& Feelders RA 2012 Fluconazole inhibits human adrenocortical stereoidogenesis in vitro. Journal of Endocrinology 215 403-412. (doi:10.1530/JOE-12-0310)

van der Pas R, Feelders RA, Gatto F, de Bruin C, Pereira AM, van Koetsveld PM, Sprij Mooij DM, Waaijers AM, Dogan F, Schulz S et al. 2013 Preoperative normalization of cortisol levels in Cushing's disease after medical treatment: consequences for somatostatin and dopamine receptor subtype expression and in vitro response to somatostatin analogs and dopamine agonists. Journal of Clinical Endocrinology and Metabolism 98 E1880-E1890. (doi:10.1210/jc.2013-1987)

Patil CG, Prevedello DM, Lad SP, Vance ML, Thorner MO, Katznelson L \& Laws ER Jr 2008 Late recurrences of Cushing's disease after initial successful transsphenoidal surgery. Journal of Clinical Endocrinology and Metabolism 93 358-362. (doi:10.1210/jc.2007-2013)

Pecori Giraldi F, Ambrogio AG, Andrioli M, Sanguin F, Karamouzis I, Corsello SM, Scaroni C, Arvat E, Pontecorvi A \& Cavagnini F 2012 Potential role for retinoic acid in patients with Cushing's disease. Journal of Clinical Endocrinology and Metabolism 97 3577-3583. (doi:10.1210/jc.2012-2328)

Pivonello R, Ferone D \& de Herder WW 2004 Dopamine receptor expression and function in corticotroph pituitary tumors. Journal of Clinical Endocrinology and Metabolism 89 2452-2462. (doi:10.1210/jc. 2003-030837)

Pivonello R, De Martino MC, Cappablanca P, De Leo M, Faggiano A, Lombardi G, Hofland LJ, Lamberts SW \& Colao A 2009 The medical treatment of Cushing's disease: effectiveness of chronic treatment with dopamine agonist cabergoline in patients unsuccessfully treated by surgery. Journal of Clinical Endocrinology and Metabolism 94 223-230. (doi:10.1210/jc.2008-1533)

Plöckinger U, Hoffmann U, Geese M, Lupp A, Buchfelder M, Flitsch J, Vajkoczy P, Jakob W, Saeger W, SchulzS etal. 2012 DG3173 (somatoprim), a unique somatostatin receptor subtypes 2-, 4- and 5-selective analogue, effectively reduces $\mathrm{GH}$ secretion in human GH-secreting pituitary adenomas even in Octreotide non-responsive tumours. European Journal of Endocrinology 166 223-234. (doi:10.1530/EJE-11-0737)

Plotsky PM, Otto S \& Sutton S 1987 Neurotransmitter modulation of corticotropin releasing factor secretion into the hypophysial-portal circulation. Life Sciences 41 1311-1317. (doi:10.1016/00243205(87)90211-6)

Pont A, Williams PL, Loose DS, Feldman D, Reitz RE, Bochra C \& Stevens DA 1982 Ketoconazole blocks adrenal steroid synthesis. Annals of Internal Medicine 97 370. (doi:10.7326/0003-4819-97-3-370)

Potts GO, Creange JE, Harding HR \& Schane HP 1978 Trilostane, an orally active inhibitor of steroid biosynthesis. Steroids 32 257-267. (doi:10.1016/0039-128X(78)90010-7)

Preda VA, Sen J, Karavitaki N \& Grossman AB 2012 Etomidate in the management of hypercortisolaemia in Cushing's syndrome: a review. European Journal of Endocrinology 167 137-143. (doi:10.1530/ EJE-12-0746)

Qian ZR, Asa SL, Siomi H, Siomi MC, Yoshimoto K, Yamada S, Wang EL, Rahman MM, Inoue H, Itakura M et al. 2009 Overexpression of HMGA2 relates to reduction of the let-7 and its relationship to clinicopathological features in pituitary adenomas. Modern Pathology 22 431-441. (doi:10.1038/modpathol.2008.202)

Reincke M, Allolio B, Kaulen D, Jarusch-Hancke C \& Winkleman W 1988 The effect of sodium valproate in Cushing's disease, Nelson's syndrome, and Addison's disease. Klinische Wochenschrift 66 686-689. (doi:10.1007/BF01726927)

Ren SG, Kim S, Taylor J, Dong J, Moreau JP, Culler MD \& Melmed S 2003 Suppression of rat and human growth hormone and prolactin secretion by a novel somatostatin/dopaminergic chimeric ligand. Journal of Clinical Endocrinology and Metabolism 88 5414-5421. (doi:10.1210/ jc.2003-030302)

Rene P, Grino M, Viollet C, Videau C, Jullian E, Bucchini D, Epelbaum J, Bertagna X \& de Keyzer Y 2002 Overexpression of the V3 vasopressin receptor in transgenic mice corticotropes leads to increased basal corticosterone. Journal of Neuroendocrinology 14 737-744. (doi:10.1046/ j.1365-2826.2002.00834.x)

Richardson UI \& Schonbrunn A 1981 Inhibition of adrenocorticotropin secretion by somatostatin in pituitary cells in culture. Endocrinology $\mathbf{1 0 8}$ 281-290. (doi:10.1210/endo-108-1-281)

Riedl M, Maier C, Zettinig G, Nowotny P, Schima W \& Luger A 2006 Long term control of hypercortisolism with fluconazole: case report and in vitro studies. European Journal of Endocrinology 154 519-524. (doi:10. 1530/eje.1.02120)

Ritzel K, Beuschlein F, Mickisch A, Osswald A, Scbeider HJ, Schopohl J \& Reincke M 2013 Clinical review: Outcome of bilateral adrenalectomy in Cushing's syndrome: a systematic review. Journal of Clinical Endocrinology and Metabolism 98 3939-3948. (doi:10.1210/jc.2013-1470)

Robinson BG, Hales IB, Henniker AJ, Ho K, Luttrell BM, Smee IR \& Stiel JN 1987 The effect of o,p'-DDD on adrenal steroid replacement therapy requirements. Clinical Endocrinology 27 437-444. (doi:10.1111/j.13652265.1987.tb01171.x)

Rocheville M, Lange DC, Kumar U, Patel SC \& Patel YC 2000 Receptors for dopamine and somatostatin formation of hetero-oligomers with enhanced functional activity. Science 288 154-157. (doi:10.1126/ science.288.5463.154)

Schonbrunn A 1982 Glucocorticoids down-regulate somatostatin receptors on pituitary cells in culture. Endocrinology 110 1147-1154. (doi:10.1210/endo-110-4-1147)

Schteingart DE, Tsao HS \& Taylor CI 1980 Sustained remission of Cushing's disease with mitotane and pitutiary irradiation. Annals of Internal Medicine 92 613-619. (doi:10.7326/0003-4819-92-5-613)

Schulte HM, Benker G, Reinwein D, Sippell WG \& Allolio P 1990 Infusion of low dose etomidate: correction of hypercortislemia in patients with Cushing's syndrome and dose-response relationship in normal subjects. Journal of Clinical Endocrinology and Metabolism 70 1426-1430. (doi:10.1210/jcem-70-5-1426)

Siler TM, Yen SC, Vale W \& Guillemin R 1974 Inhibition by somatostatin on the release of TSH induced in man by thyrotropin-releasing factor. Journal of Clinical Endocrinology and Metabolism 38 742-745. (doi:10.1210/jcem-38-5-742) 
Silva AP, Bethmann K, Raulf F \& Schmid HA 2005 Regulation of ghrelin secretion by somatostatin analog in rats. European Journal of Endocrinology 152 887-894. (doi:10.1530/eje.1.01914)

Sonino N 1987 The use of ketoconazole as an inhibitor of steroid production. New England Journal of Medicine 317 812-818. (doi:10.1056/NEJM198709243171307)

Sonino N \& Boscaro M 1999 Medical therapy for Cushing's disease. Endocrinology and Metabolism Clinics of North America 28 211-222. (doi:10.1016/S0889-8529(05)70064-5)

Sonino N, Boscaro M, Paoletta A, Mantero F \& Ziliotto D 1991 Ketoconazole treatment in Cushing's syndrome: experience in 34 patients. Clinical Endocrinology 35 347-352. (doi:10.1111/j.1365-2265.1991.tb03547.x)

Sonino N, Boscaro M, Fallo F \& Fava G 1992 Potential therapeutic effects of ritanserin in Cushing's disease. Journal of the American Medical Association 267 1073. (doi:10.1001/jama.1992.03480080043020)

Southren AL, Weinsenfeld S, Laufer A \& Goldner MG 1961 Effect of $\mathrm{o}, \mathrm{p}^{\prime} \mathrm{DDD}$ in a patient with Cushing's síndrome. Journal of Clinical Endocrinology and Metabolism 21 201-208. (doi:10.1210/jcem-21-2-201)

Stalla GK, Brockmeier SJ, Renner U, Newton C, Buchfelder M, Stalla J \& Müller OA 1994 Octreotide exerts different effects in vivo and in vitro in Cushing's disease. European Journal of Endocrinology 130 125-131. (doi:10.1530/eje.0.1300125)

Stenzel-Poore MP, Cameron VA, Vaughn J, Sawchenko PE \& Vale W 1992 Development of Cushing's syndrome in corticotropin-releasing factor transgenic mice. Endocrinology 130 3378-3386. (doi:10.1210/endo.130. 6.1597149)

Suda T, Tozawa F, Mouri T, Sasaki A, Shibasaki T, Demura H \& Shizume K 1983 Effects of cyproheptadine, reserpine, and synthetic corticotroph releasing factor on pituitary glands from patients with Cushing's disease. Journal of Clinical Endocrinology and Metabolism 56 1094-1099. (doi:10.1210/jcem-56-6-1094)

Sugar AM, Alsip GA, Craven PC \& Stevens DA 1987 Pharmacology and toxicity of high-dose ketoconazole. Antimicrobial Agents and Chemotherapy 31 1874-1878. (doi:10.1128/AAC.31.12.1874)

Suri D \& Weiss RE 2005 Effect of pioglitazone on adrenocorticotropic hormone and cortisol secretion in Cushing's disease. Journal of Clinical Endocrinology and Metabolism 90 1340-1346. (doi:10.1210/ jc.2004-1746)

Syro LV, Ortiz LD, Scheithauer BW, Lloyd R, Lau Q, Gonzalez R, Uribe H, Cusimano M, Kovacs K \& Horvath E 2011 Treatment of pitutiary neoplasms with temozolomide: a review. Cancer $117454-462$. (doi:10.1002/cncr.25413)

Tabarin A, Navarranne A, Guerin J, Corcuff JB, Parmiex M \& Roger P 1991 Use of ketaconazole in the treatment of Cushing's disease and ectopic ACTH syndrome. Clinical Endocrinology 34 63-69. (doi:10.1111/ j.1365-2265.1991.tb01737.x)
Tanakol R, Alagol F, Azizlerli H, Sandalci O, Terzioglu T \& Berker F 1996 Cyproheptadine treatment in Cushing's disease. Journal of Endocrinological Investigation 19 242-247. (doi:10.1007/BF03349875)

Thorn GW, Renold AE, Goldfien A, Nelson DH, Reddy WJ \& Hertz R 1956 Inhibition of corticosteroid secretion by amphenone in a patient with adrenocortical carcinoma. New England Journal of Medicine $\mathbf{2 5 4}$ 547-551. (doi:10.1056/NEJM195603222541202)

Tritos NA, Biller BM \& Swearingen B 2011 Management of Cushing disease. Nature Reviews. Endocrinology 7 279-289. (doi:10.1038/nrendo.2011.12)

Vale W, Rivier C, Brazeau P \& Guillemin R 1974 Effects of somatostatin on the secretion by thyrotropin and prolactin. Endocrinology 95 968-977. (doi:10.1210/endo-95-4-968)

Van Cauter E \& Refetoff S 1985 Evidence of two subtypes of Cushing's disease based on the analysis of episodic cortisol secretion. New England Journal of Medicine 312 1343-1349. (doi:10.1056/NEJM198505 233122102)

Van der Lely AJ, Fockin K, Van der Mast RC \& Lamberts SW 1991 Rapid reversal of acute psychosis in the Cushing syndrome with the cortisol-receptor antagonist mifepristone (RU-486). Annals of Internal Medicine 114 143-144. (doi:10.7326/0003-4819-114-2-143)

Verhelst JA, Trainer FJ, Howlett TA, Perry L, Rees LH, Grossman AB, Wass AH \& Besser GM 1991 Short and long-term responses to metyrapone in the medical management of 91 patients with Cushing's syndrome. Clinical Endocrinology 35 169-178. (doi:10.1111/j.1365-2265.1991. tb03517.x)

Vignati F \& Loli P 1996 Additive effect of ketoconazole and octreotide in the treatment of severe adrenocorticotropin-dependent hypercortisolism. Journal of Clinical Endocrinology and Metabolism 81 2885-2890. (doi:10.1210/jcem.81.8.8768846)

Vilar L, Naves LA, Azevedo MF, Arruda MJ, Arahata CM, Moura E, Silva L, Agra L, Pontes L, Montenegro L et al. 2010 Effectiveness of cabergoline in monotherapy and combined with ketoconazole in the management of Cushing's disease. Pituitary 13 123-129. (doi:10.1007/s11102-0090209-8)

Walsh LP, Kuratko CN \& Stocco DM 2000 Econzale and miconazole inhibit steroidogenesis and disrupt steroidogenic acute regulatory (StAR) protein expression post-transcriptionally. Journal of Steroid Biochemistry and Molecular Biology 75 229-236. (doi:10.1016/S09600760(00)00170-9)

Yin D, Kondo S, Takeuchi J \& Morimura T 1994 Induction of apoptosis in murine ACTH-secreting pituitary adenoma cells by bromocriptine. FEBS Letters 339 73-75. (doi:10.1016/0014-5793(94)80387-0)

Young WF Jr \& Thompson GB 2005 Laparoscopic adrenalectomy for patients who have Cushing's syndrome. Endocrinology and Metabolism Clinics of North America 34 489-499. (doi:10.1016/j.ecl.2005.01.006)

Received in final form 31 July 2014

Accepted 18 August 2014

Accepted Preprint published online 18 August 2014 http://joe.endocrinology-journals.org DOI: 10.1530/JOE-14-0300
() 2014 Society for Endocrinology Printed in Great Britain
Published by Bioscientifica Ltd. 